NBER WORKING PAPER SERIES

\title{
INFORMATION FRICTIONS AND ACCESS TO THE PAYCHECK PROTECTION PROGRAM
}

Christopher Neilson

John Eric Humphries

Gabriel Ulyssea

Working Paper 27624

http://www.nber.org/papers/w27624

\author{
NATIONAL BUREAU OF ECONOMIC RESEARCH \\ 1050 Massachusetts Avenue \\ Cambridge, MA 02138
}

July 2020

We would like to thank Princeton University's Industrial Relations Section and Yale University's Tobin Center for Economic Policy for financially supporting this work. We would also like to thank Mariel Bedoya, Michael Borger, Iliana Cabral, Franco Calle, Alvaro Carril, Alejadrina Correa, Richard De Thorpe, Deniz Dutz, Maria Elena Guerrero, Isabel Jacas, Katherine Kwok, Manuel Martinez, Cecilia Moreira, Naomi Shimberg, Ignacio Riveros, Eduardo Vargas and Yagmur Yuksel for helpful research assistance on this project. The views expressed herein are those of the authors and do not necessarily reflect the views of the National Bureau of Economic Research.

NBER working papers are circulated for discussion and comment purposes. They have not been peer-reviewed or been subject to the review by the NBER Board of Directors that accompanies official NBER publications.

(C) 2020 by Christopher Neilson, John Eric Humphries, and Gabriel Ulyssea. All rights reserved. Short sections of text, not to exceed two paragraphs, may be quoted without explicit permission provided that full credit, including $(\odot$ notice, is given to the source. 
Information Frictions and Access to the Paycheck Protection Program

Christopher Neilson, John Eric Humphries, and Gabriel Ulyssea

NBER Working Paper No. 27624

July 2020

JEL No. H0,J01,J08

\begin{abstract}
$\underline{\text { ABSTRACT }}$
The Paycheck Protection Program (PPP) extended 669 billion dollars of forgivable loans in an unprecedented effort to support small businesses affected by the COVID-19 crisis. This paper provides evidence that information frictions and the "first-come, first-served" design of the PPP program skewed its resources towards larger firms and may have permanently reduced its effectiveness. Using new daily survey data on small businesses in the U.S., we show that the smallest businesses were less aware of the PPP and less likely to apply. If they did apply, the smallest businesses applied later, faced longer processing times, and were less likely to have their application approved. These frictions may have mattered, as businesses that received aid report fewer layoffs, higher employment, and improved expectations about the future.
\end{abstract}

Christopher Neilson

School of Public and International Affairs

Princeton University

Firestone Library, Room A2H

Princeton, NJ 08544

and NBER

cneilson@princeton.edu

John Eric Humphries

Department of Economics

Yale University

37 Hillhouse Ave

New Haven, CT 06511

johneric.humphries@yale.edu
Gabriel Ulyssea

University of Oxford

Department of Economics

Manor Road Building

Manor Road

Oxford, OX1 3UQ

United Kingdom

gabriel.ulyssea@economics.ox.ac.uk

A Project Website is available at https://covid19sbs.org/ 


\section{Introduction}

The coronavirus epidemic has had a broad impact on public health in the United States, with 3.7 million cases and more than 139 thousand deaths reported by July 19th, 2020 (Center for Disease Control, 2020). As a response, most states have introduced strong social distancing measures, including stay-at-home orders and closure of non-essential businesses. These measures are likely to have severe effects on small and medium enterprises, as they tend to be more concentrated in sectors directly affected (e.g. retail and services) and are typically more credit constrained than larger businesses. ${ }^{1}$ As a response to the crisis, on March 27th the U.S. Congress passed The Coronavirus Aid, Relief, and Economic Security (CARES) Act, which included 349 billion dollars (later expanded to 669 billion dollars) to fund the Paycheck Protection Program (PPP). The PPP was designed to support small businesses by extending government-backed loans that can be partially or fully forgiven if certain conditions are met.

This paper provides evidence that, despite the unprecedented amount of aid, the combination of information frictions and PPP's "first-come, first-served" design disadvantaged the smallest businesses. This disadvantage in getting aid may have large implications. While we cannot claim causality, we show that businesses that received aid report fewer layoffs and improved expectations about their businesses survival and recovery, with smaller firms showing the largest improvements. However, our results also show that the smallest businesses were less aware of the PPP and less likely to apply. Among businesses that applied for the PPP, smaller businesses applied later, faced longer processing times, and were less likely to have their applications approved. Taken together, this evidence suggests that information frictions, as well as other frictions in the application process, may have disadvantaged small businesses. ${ }^{2}$

Our data come from daily surveys that began on March 28th, the day after the CARES Act was passed, and continued through May 16th. Early respondents were also asked to complete follow-up surveys that began on April 19th, the day that the PPP exhausted its initial funding, and continued through May 16th. Survey participants were recruited via social media ads targeted at small business owners across the United States that had been affected by COVID19. The sample includes data from more than 14,000 small business owners in the U.S., with follow-up surveys for almost 3,000 small business owners. The surveys collected information on initial firm size, layoffs, beliefs about businesses' future prospects, and their awareness of existing

\footnotetext{
${ }^{1}$ These businesses make up the majority of companies in the U.S., and are responsible for a substantial fraction of employment. Firms with fewer than 20 employees account for $89 \%$ of firms and $16.4 \%$ of employment (2017 Census of US Businesses).

${ }^{2}$ By information frictions, we mean impediments to awareness of the program, including awareness of how the program and forgiveness of the loans work, who is eligible, and how to apply.
} 
government relief programs that could help their firms. In addition, we collected information about their experiences seeking aid, the current status of their applications, and difficulties they faced during the application process.

We document four key facts. First, respondents' expectations about the future are generally negative and deteriorated over the three to four weeks following the passing of the CARES Act. In the first week of the survey, $64 \%$ of respondents believed their businesses would recover within two years, but this number steadily decreases until late April, when it levels out or slightly reverses. The latter movement corresponds to the period of time when it was clear that the PPP would continue to be funded. However, after a short period, most outcomes continue to deteriorate. In the last week of the survey, only $48 \%$ of firms report that they expect their businesses to recover within two years. We observe the same patterns for the proportion of respondents who think their businesses will ever recover. These results hold when controlling for a rich set of covariates and when using changes over time within firm.

Second, the smallest businesses were slower to become aware of government programs. ${ }^{3}$ The day after the CARES Act was passed (March 28th), businesses with fewer than 10 full-time equivalent (FTE) employees were much less likely to know about any government programs designed to support small businesses when compared to larger firms with 10 to 50 employees. Despite large initial information differences, the proportion of businesses with 5 to $9.5 \mathrm{FTE}$ employees that knew about government programs rapidly increased, reaching levels similar to larger firms (above 90\%) a day or two after the program started accepting applications. In contrast, around $68 \%$ of businesses with fewer than five employees reported knowing about government programs that could help their business when PPP applications were open, and this share remained below $80 \%$ through April 16th, when the PPP exhausted its initial funding. Given the "first-come, first-served" nature of the program, information asymmetries early on may have resulted in the smaller firms missing out on the first round of PPP loans.

Third, the smallest firms were less likely to apply for the PPP and, conditional on applying, they applied later, waited longer for their application to be approved, and were less likely to get approval. Firms with 0 to 4.5 FTE employees were 23 percentage points less likely to apply for PPP loans compared to firms with 10 to 50 employees. Conditional on applying, businesses with fewer than five employees applied two days later, and were 27 percentage points less likely to have received approval. Conditional on receiving a PPP loan, businesses with 0 to 4.5 employees waited around two days longer for their application to be approved. These patterns, in particular

\footnotetext{
${ }^{3}$ Throughout this paper, we divide firms into three size bins based on the number of full-time equivalent employees: (1) 0-4.5 FTE employees, (2) 5-9.5 FTE employees, (3) 10-50 FTE employees.
} 
longer wait times, are also consistent with other frictions in the application process, such as differential access or differing existing relationships with banks that made a larger number of PPP loans (see Granja et al. (2020)).

Fourth, businesses that received a PPP loan report more employees, lower probabilities of closure or bankruptcy, and higher probabilities of recovering in the next two years. While it is difficult to establish causality, this finding holds after controlling for the characteristics of the business, the owner, and location dummies. Conditional on applying for a PPP loan, those that are approved are, on average, 12 percentage points more likely to report that they will recover in the next two years, and reported probabilities of bankruptcy or closure that are 8 percentage points lower. They are also 9 percentage points less likely to report having fewer workers than in January. All of these effects are stronger for smaller businesses (with fewer than 10 employees).

Taken together, the four facts indicate that information frictions hindered the ability of small businesses to access PPP resources. These frictions may have been driven by differential awareness of the PPP program early on, but uncertainty about eligibility criteria or the forgivable aspect of the loan likely also contributed. Even if only present during the beginning of the PPP, these frictions may have had real negative consequences for small businesses. Firms' expectations about the future fell sharply in the first month of the survey, which may have led firms to lay off the majority of their workers or shut down completely within this short time frame. These actions may be costly to reverse, especially since the CARES Act also increased unemployment insurance benefits by $\$ 600$ per week. Since full loan forgiveness requires firms to maintain payroll at pre-crisis levels during the eight weeks following initiation of the loan, firms that failed to apply for the PPP early on may no longer benefit from it. Moreover, since payroll is the main forgivable component of the loan, this could have further reduced the attractiveness of the subsequent 2nd round of PPP funding that is set to close in early August.

\section{Related literature}

This paper contributes to a small but rapidly growing literature on the economic impacts of COVID-19 on small businesses. Closely related work by Bartik et al. (2020) surveys 5,800 U.S. small businesses through Alignable, a network-based platform for small businesses. Their survey reached somewhat larger businesses and found that the majority planned to seek funds through the CARES Act, which is consistent with our findings for the larger small businesses (over 5 employees) in our sample. Fairlie (2020b) and Fairlie (2020a) similarly provides evidence on the

impact of COVID-19 on small businesses using the April and May Consumer Population Surveys 
- a population-representative data set and shows that the number of active small business owners fell by 22 percent from February to April 2020, with a partial rebound in May.

Another set of recent papers specifically studies the impact of the PPP. Granja et al. (2020) use administrative data on the distribution of PPP loans and high-frequency micro-level employment data to evaluate how well the CARES Act targeted businesses in need. They conclude that funds flowed to areas that were less impacted by the economic crisis in terms of declines in hours worked or business shutdowns. Their results also indicate that access to banks that participated heavily in PPP lending may be an important determinant of access to the program. While we argue that our results imply that information frictions play a central role, some of our facts are also consistent with smaller businesses facing larger frictions in the application process that are related to access to banks (such as lower application rates, and longer processing times).

Chetty et al. (2020) studies the impacts of a number of stabilization policies using data from private companies and finds little evidence that PPP loans affected employment. However, they analyze firms much larger than those in our sample, focusing on firms around the 500 employee cutoff for PPP eligibility. In contrast, less than $1 \%$ of firms in our sample have more than 50 employees. Compared to these larger firms, those in our sample may have fewer sources of liquidity, smaller reserves, and less extensive existing relationships with banks. They are also less likely to have dedicated human resources or accounting staff who may help determine the requirements of PPP loans and how to apply. ${ }^{4}$ Autor et al. (2020) uses a similar design to study the impacts of the PPP. Using payroll processing data from ADP, the paper studies the impacts of the PPP using high-frequency employment data and estimates the PPP increased employment by 2.3 million.

Other work has focused on the effects of COVID-19 on employment. Adams-Prassl et al. (2020) uses real-time survey evidence to analyze the impacts of the COVID-19 containment measures on workers in the U.S. and the UK. Most relevant for the results discussed in this paper, they document substantial negative effects on workers in the U.S. in their first wave of data (collected on March 24-25, 2020), which is consistent with the strong effects on lay-offs that we document here. ${ }^{5}$ Kahn et al. (2020) show that job vacancies fell more than $30 \%$ compared to the beginning of 2020 and align closely with the number of new UI claims filed across the U.S.

\footnotetext{
${ }^{4}$ Cororaton and Rosen (2020) also studies the PPP, but focus on utilization of PPP loans by publicly traded companies. The paper studies the 273 public firms that received almost one billion dollars in PPP loans in April. The paper finds that, among publicly traded firms, those that received funds tended to be smaller and in counties with more COVID-19 cases.

${ }^{5}$ As part of their main analysis, the authors document substantial inequality in the observed effects, as workers without a college degree and women are more severely affected. Beland et al. (2020) finds similar results for the US using data from the Current Population Survey (CPS).
} 
Cajner et al. (2020) uses payroll processing data to show that aggregate payroll fell 21 percent by late April with a small recovery through late May, with the largest impacts among lower-paid workers. These results are consistent with Coibion et al. (2020), who use surveys of households in the Nielsen Homescan data to document that over 20 million people lost their jobs by early April and that many were not seeking new employment (with a 7 percentage point drop in labor force participation). ${ }^{6}$

The paper is also related to a large literature studying how broadly defined information frictions, behavioral biases, and transaction costs can affect the take-up and targeting of social programs. Theoretical and empirical evidence suggest that ordeal mechanisms or transaction costs associated with applying for aid can improve targeting of social programs (Besley and Coate, 1992). Yet, there is also ample evidence that even individuals who would greatly benefit from government assistance programs may not take advantage of them due to a lack of information, sophistication, or ability to optimize. For example, Bettinger et al. (2012) provide evidence that low income students are more likely to access financial aid and attend college when they receive limited assistance with filling out FASFA applications. Bhargava and Manoli (2015) shows that low awareness and understanding of EITC benefits lead to lower take-up. Importantly, Bhargava and Manoli (2015) highlights that information frictions also include knowledge of how EITC works and who is eligible, and not just knowledge of the program's existence. Finkelstein and Notowidigdo (2019) similarly shows that improving information and reducing transaction costs can lead to higher take-up in the case of food stamps, but also lead to reduced targeting. While not focused on information frictions, this paper is also related to Zwick and Mahon (2017), which studies barriers to program take up for firms. Studying a temporary policy which allows for bonus depreciation of capital, the paper finds evidence of financial frictions or fixed costs affecting firms' utilization of the policy.

\section{Institutional Background and Data}

\subsection{The Paycheck Protection Program (PPP)}

The Coronavirus Aid, Relief, and Economic Security (CARES) Act was passed by Congress and signed into law on March 27th, 2020. This large relief package (over USD 2 trillion) established the Paycheck Protection Program (PPP), which was aimed to provide small businesses with a temporary source of liquidity in the form of forgivable loans. These loans are designed to help

\footnotetext{
${ }^{6}$ See also Barrero et al. (2020), which discusses the reallocation effects of the shock, and specifically discusses the impacts of increased unemployment insurance benefits.
} 
cover payroll costs and additional fixed expenses during the COVID-19 pandemic.

The maximum loan amount in the program is the minimum between 2.5 times the average monthly payroll costs and ten million dollars. The interest rate on all loans is $1 \%$ and their maturity is two years. The loans are forgivable when used to cover payroll costs, mortgage interest, rent, or utilities, with the additional requirement that $75 \%$ of the total forgiven amount must be payroll. ${ }^{7}$ The loans do not require collateral or personal guarantees, and can be deferred for six months. To get access to these funds, firms must apply through an authorized Small Business Administration (SBA) lender.

A key aspect of the PPP is that the loans are forgivable only if the employer maintains the number of employees and salary levels at pre-COVID-19 levels, or if those are restored by June 30,2020 . If the number of employees or salary levels are reduced, the amount forgivable is also reduced. ${ }^{8}$ The PPP started accepting applications on April 3rd, and the initial funding of $\$ 349$ billion was exhausted by April 16th. New legislation was signed on April 24th, which included an additional $\$ 320$ billion dollars in funding for the PPP after the program reopened to applications on April 27th. Appendix A provides additional details on the PPP.

\subsection{The Small Business Survey Data}

We collect new survey data on small businesses in the U.S. to understand the impacts of the COVID-19 crisis, and the challenges it created. We recruited the sample of participants via social media ads targeted at small and medium sized business owners in the United States who had been affected by the COVID-19 crisis. $^{9}$ Recruitment began on March 28th, one day after the CARES Act was passed, and we continuously received baseline responses through May 16th. The responses are distributed relatively uniformly throughout the sampling period, though there are fewer respondents in the first four days and last week of the survey. Appendix Table 3 reports the number of survey responses by day.

The core of the baseline survey contains a set of questions about firm characteristics, including size (as measured by the number of full- and part-time employees) and the number of laid-off employees since January. The survey also asks small business owners to report their beliefs about the future. More specifically, we ask owners how many employees they expect to lay off within the next two months, if they believe their businesses will recover in the next

\footnotetext{
${ }^{7}$ The Paycheck Protection Program Flexibility Act, signed into law on June 5th, changed the requirement from $75 \%$ to $60 \%$. Similarly, it changed the maturity date from two to five years.

${ }^{8}$ More detailed information is available at https://home.treasury.gov/policy-issues/cares/ assistance-for-small-businesses.

${ }^{9}$ The Appendix Section B provides more details about the survey and contains the survey instrument.
} 
two years, if they think their businesses will ever recover, and the probability that they will shutdown or go bankrupt within the next six months. We also measure awareness of existing state and federal programs available to help small businesses cope with the COVID-19 crisis. $^{10}$ On April 27th, the baseline survey was expanded to include a broader set of questions, with a particular focus on respondent's access to the PPP. We ask if and when the respondent applied and about the outcome of their application. The overall baseline sample consists of 14,208 adult small business owners in the United States who completed the survey by May 16th, $2020 .{ }^{11}$ Of those, 11,104 completed the short baseline survey and 3,104 completed the expanded baseline survey.

A follow-up survey was launched on April 19th targeting those who completed the short baseline survey. It repeated questions about employment and expectations, and included the more comprehensive set of questions used in the extended baseline survey about the PPP. The follow-up survey was completed by 2,768 of the respondents.

While we did not construct the survey to be representative of the population of firms in the U.S., the size distribution in the data is similar to the firm size distribution in the 2017 Census of U.S. Businesses, as shown in Figure 5 in the Appendix. The survey includes responses from all 50 states and the District of Columbia. The states with the most responses were New York, California, Pennsylvania, Michigan, Illinois, Florida, and Texas, but there are over 30 responses from each state (including Alaska and Hawaii). ${ }^{12}$ New England, the upper mid-west, and the Northwest are somewhat over-represented in the survey relative to the number of firms with fewer than 500 employees in each state, while California and the south are somewhat under-represented (See Appendix Figure 6). Using the US Census Small Business Pulse Survey, Appendix Figures 7 and 8 also show that trends in obtaining PPP loans and beliefs about recovery by firm size are similar in our survey and the Census's nationally-representative sample, though firms in our survey have slightly lower PPP acquisition rates and worse beliefs about recovery.

For the analysis in this paper, we restrict our sample to respondents who report having fifty or fewer FTE employees in January 2020 and who completed at least the employment portion of the survey (firms larger than 50 employees represent only 1\% of respondents). Appendix Table 4 summarizes the baseline survey responses. The table shows that, on average, respondents had 4.88 FTE employees in January, though the number of employees is right skewed, with a median

\footnotetext{
${ }^{10}$ Specifically, the survey asks "Are you aware of any federal or state programs that could help your business during this crisis?" and, thus, likely captures both awareness of the program and comprehension of how the program works and who is eligible.

${ }^{11}$ We include responses where the respondent consented to the survey and completed at least the initial questions regarding employment in January, layoffs to date, and planned layoffs.

${ }^{12}$ Appendix Figure 4 maps the distribution of survey responses by state.
} 
of $2.5 .79 \%$ of the sample expects to recover eventually, with $57 \%$ expecting to recover in the next two years. Finally, on average, awareness of government programs to help businesses was high $(79 \%)$, but lower for programs specifically designed to help business cover wages of their employees $(68 \%)$. The bottom panel of the table summarizes the additional outcomes from the follow-up and expanded baseline surveys. Using this subsample, $53 \%$ applied for a PPP loan and $37 \%$ of those who applied were approved.

\section{Results}

This section outlines four sets of results. First, we document how layoffs and expectations of small businesses evolved from March 28th to May 16th. Second, we provide evidence that the smallest businesses were substantially less informed about available government programs that could help their business, and that this gap remains large throughout the sampling period. Third, smaller businesses were less likely to apply for the PPP and, conditional on applying, they applied later, were less likely to get approval, and waited longer for their application to be approved. Fourth, we document that receiving a PPP loan is associated with a notable improvement in expectations about the future and a small increase in current employment.

\subsection{Evolution of layoffs and expectations}

The first set of results investigates the evolution of responses for the 50 days after the the CARES Act was passed. We chart the responses over time, which provide a repeated cross section of respondents. This provides insights into how businesses have adjusted to the disruption and how their expectations about the future have evolved. Overall, we see that employment fell sharply in the first two weeks after the passage of the CARES Act, and has largely leveled off or slightly improved since mid-April. While employment has improved somewhat, expectations for the future have not, with a continued decline over the length of the survey.

Figure 1 summarizes the trends over time using daily survey responses. The top panel provides evidence on how employment decisions have changed for small businesses. The top left plot shows the time trend for whether businesses have laid off any workers since January while the top right figure shows the proportion of workers from January currently employed at the firm. The black line is loess regression fit to the data with the grey region showing the 95\% confidence interval. The blue line plots a moving average over 250 responses. The light red vertical lines show key dates: when the CARES Act was signed, when PPP applications opened to most businesses, when PPP applications opened to the self-employed and independent 
contractors, when the initial funding for the PPP was exhausted, and when legislation was signed to replenish PPP funds. In the first three weeks, there was an upward trend in the proportion of small businesses that have had to lay off employees - increasing by approximately 10 percentage points. The top right figure provides similar evidence by plotting the proportion of employees from January who are still employed. This figure shows a decline of more than 10 percentage points from late March through mid April. In the last three weeks, the proportion of firms that have laid off employees levels off, while the proportion of workers from January currently working changes sign and moderately increases.

While layoffs were concentrated in the first three weeks, expectations about the future declined over the entire fifty days. The bottom row of Figure 1 shows the trends for the proportion of firms that expect to recover in the next two years (left), and the proportion that expect to ever recover (right). Both expectations sharply declined by more than 10 percentage points through late April. Expectations temporarily leveled off before then declining further in the last two weeks of the survey.

One concern with the visual evidence presented above is that the sample of respondents may change over time. To address this concern, we provide three pieces of evidence in Appendix D. First, the composition of firm size - based on employment in January - has remained consistent across the survey. Second, we show that these trends hold when controlling for state dummies, cubic polynomials for full-time and part-time employment in January, and the day of the week on which the survey was taken. ${ }^{13}$ Third, we use the follow-up survey to directly measure changes within firms and to control for additional firm characteristics. Appendix Table 6 uses the followup survey to regress within-firm change on the elapsed number of days between the baseline survey and the follow-up. The regression controls for full-time and part-time employment in January, state dummies, day of the week when the baseline survey was taken, owner's years of education, sex, age group, dummies for the type of firm, dummies for sector, and dummies for the week the baseline survey was taken. The table shows that for each elapsed day the probability of recovering in the next two years falls by 0.004 , the probability of ever recovering falls by 0.002 . The probability of past layoffs shows a large initial increase in layoffs ( 0.076 for the week of April 1st), which then levels off or slightly decreases in later weeks - similar to what is shown in Figure 1. These results thus confirm that the trends in Figure 1 are not likely driven by changes in sample composition over time.

\footnotetext{
${ }^{13}$ Barrios and Hochberg (2020) show that some states were less likely to implement or comply with preventative health measures such as social distancing. They show that these behaviors are correlated with perceived risk, and show that places with more support for President Trump were less likely to follow preventative health measures. State fixed-effects provide proxies for persistent differences in behaviors and perceived risks across states.
} 


\subsection{Information frictions}

In contrast to the declining expectations of respondents over the first three to four weeks of the survey, small business owners rapidly became aware of programs that could help them. Yet, the levels and trends in awareness differ substantially by the initial size of the business. The survey question asks specifically about awareness of aid that could help the respondent's business, and thus it captures a combination of awareness as well as comprehension of existing programs.

The top panel of Figure 2 shows the time trends in survey respondents' awareness of any federal state programs that could help their businesses. Awareness increases substantially over the first three weeks, with over $70 \%$ of businesses reporting that they were aware of programs when PPP applications opened, increasing to over $80 \%$ on April 16th when the PPP exhausted its initial funding. In late April, we see a slight downturn in awareness, which may be related to the fact that the awareness question specifically asks if individuals are aware of programs that "could help your business". Thus, this slight downturn could be reflecting businesses realizing the PPP may not help them if they had already laid off their employees. ${ }^{14}$

The lower panel of Figure 2 breaks out the trends by business size, showing the trends for businesses with fewer than five FTE employees, five to 9.5 FTE employees, and ten to fifty FTE employees. There are substantial gaps in awareness across firm size bins from the onset, as well as marked differences in their evolution over the first three weeks. Businesses with 10-50 FTE employees were highly aware of programs that could help their business throughout the sample. In comparison, businesses with 0 to 4.5 and 5 to 9.5 employees were much less likely to be aware of programs immediately after the CARES Act was passed. Yet, these two groups had very different trends in awareness over time. Businesses with 5 to 9.5 employees rapidly became more aware of programs, reaching similar levels as those of larger businesses around the time the PPP opened for applications. In contrast, businesses with fewer than five employees learned about programs much more slowly, with a large gap persisting through when the PPP exhausted its initial funding and never closing completely.

In late April, we see awareness of programs falling for the smallest businesses. One explanation for this decline is that, as details of how forgiveness of PPP loans worked became more widely known, small businesses realized that the program would not (or no longer) be helpful to them. Specifically, two characteristics of the PPP are key: (i) $75 \%$ of the forgiven amount of the loan was required to be payroll; and (ii) employment levels were required to be at pre-crisis

\footnotetext{
${ }^{14}$ Appendix D.1 provides similar results specifically for programs that provide subsidized loans and programs that help cover payroll.
} 
levels. ${ }^{15}$ If small businesses had already laid off their employees, qualifying for forgiveness would be more challenging. ${ }^{16}$

Overall, the patterns are consistent with smaller businesses facing larger information frictions, where we define information frictions as impediments to awareness of the program, including awareness of how the program and forgiveness of the loans work, who is eligible, and how to apply. Although the above patterns may seem consistent with smaller firms having less need for assistance and thus remaining less informed, our data does not support this conclusion. Compared to firms with 10 or more employees in the baseline survey, firms with fewer than 5 employees were only 1 percentage point less likely to report that they expected to ever recover, and reported probabilities of bankruptcy or permanent closure 2 percentage points higher.

\subsection{Frictions in getting PPP loans}

Consistent with the differential rates of awareness, we also find that larger businesses were much more likely to apply for PPP loans, and to get approved conditional on applying. Using the follow-up survey and the extended baseline survey described in Section 2.2, we collect information on whether the business applied for a PPP loan, when the application was submitted, the outcome of the application, and how long it took for the application to be approved. Table 1 shows how these outcomes are predicted by firm characteristics. The first column reports results from regressing an indicator for getting a PPP loan on firm characteristics. ${ }^{17}$ Businesses with fewer than 5 employees were 23 percentage points less likely to apply than businesses with 10 to 50 employees, while firms with 5 to 9.5 employees applied at approximately the same rate as these larger businesses. Those with more education were more likely to apply, and compared to omitted category of C-Corps and S-Corps - the self-employed, sole proprietorships, and partnerships were substantially less likely to apply.

The first column shows that firm size and sophistication were important predictors of getting a PPP loan, which combines the decision to apply and the outcome of the application. The second and third columns report the same regression for the decision to apply, and receiving a PPP loan conditional on applying, respectively. Both the decision to apply and getting approved conditional on applying are positively correlated with firm size, years of education, and the type

\footnotetext{
${ }^{15}$ See Appendix A for details on the PPP and additional changes to the rules introduced in June.

${ }^{16}$ While we cannot provide direct quantitative evidence on these mechanisms, they are consistent with several of the open-ended responses collected at the end of survey.

${ }^{17}$ All regressions in this table control for firm size, firm type, firm sector, the respondent's years of education, an indicator for being female, age bins, state dummies, and the date the survey was taken. The final column controls for the date the application was submitted and the week the survey was taken.
} 
of firm. While we do not have exogenous variation in the decision to apply, it is informative that larger firms were more likely to have their PPP loans approved even after conditioning on those who applied and controlling for a rich set of firm characteristics. ${ }^{18}$

Consistent with information frictions differentially affecting smaller businesses, we also find that smaller firms applied later. The fourth column of Table 1 runs the same regression, but on how many days it took the firm to apply (conditional on applying). The results show that firms with fewer than five employees applied an average of 1.8 days later. Finally, the fifth column of the table regresses the average wait time for approval on firm characteristics among the firms that were approved. The smallest firms waited, on average 1.8 days longer for approval, while firms with 5 to 9.5 employees waited 0.6 days longer, though this second coefficient is not statistically significant. The final column also shows that the self-employed waited substantially longer for approval.

While our results are largely consistent with information frictions playing a central role, lower rates of getting a PPP loan conditional on applying, and longer delays when waiting for approval are also consistent with other mechanisms. For example, Granja et al. (2020) shows that access to banks which participated heavily in PPP lending may have been an important determinant in getting a PPP loan, which would be consistent with some of the facts we document. Nevertheless, Appendix Table 7 provides some evidence that geographic proximity to financial institutions offering PPP loans are not confounding the estimates on firm size in Table 1. ${ }^{19}$ Another possibility is that the self-employed reported being unaware of programs until the PPP program opened to self-employed workers on April 10th. Figure 2 shows that awareness of programs was still substantially lower on April 10th for the smallest firms. Appendix Table 9 additionally breaks out firms with 0 employees (which are more likely to be sole-proprietors or self-employed), and we show that firms with 0.5 to 4.5 employees remain much less likely to apply for PPP loans compared to larger firms.

\subsection{The impact of getting the PPP on expectations and employment}

We find that getting a PPP loan was associated with substantially better expectations about the future and having moderately more employees. Table 2 regresses outcomes on an indicator

\footnotetext{
${ }^{18}$ Given that the survey ran through May 16th, some of the differences in approval rates (conditional on applying) are likely due to loans having not yet been approved, rather than applications being rejected. This is consistent with column 4 of Table 1, which shows smaller firms applied later.

${ }^{19}$ Along with local demographic information and state case and death counts, Appendix Table 7 additionally controls for the minimum distance from the centroid of the respondent's ZIP code to the closest SBA approved lender, the number of SBA approved lenders within 10 kilometers. Adding these controls have little effect on the coefficients.
} 
for receiving a PPP loan and a rich set of controls. For each outcome, the first row includes the whole sample of individuals who were asked about PPP loans, while the second row restricts to those who applied for PPP loans. Columns show results for the full sample, as well as regressions conditional on firm size. Overall, getting a PPP loan is associated with notable improvements in expectations: the probability of recovery within two years increases by 0.08 , and the probability of closure or bankruptcy in the next six months decreases by 0.08 . When conditioning only on those who applied for a PPP loan, the results are larger, with a 0.12 increase in the probability of recovering within two years and a 0.11 reduction in the probability of closure or bankruptcy in the next six months. These effects are largely similar across firm size bins, though they are larger and have smaller standard errors for firms with fewer than five employees.

The last two panels report the same regressions with current employment and an indicator for if the firm has any reduction in employment since January as the outcome variables. Those who received a PPP loan reported slightly more employees. In addition, they are 9 percentage points less likely to have fewer employees than in January.

Establishing causality is difficult in this setting, as we cannot fully control for self-selection (though our main specification includes many business-specific controls). Firms may have been more likely to apply for and get a PPP loan if they were better-off to begin with, or who were in locations less effected by COVID-19. In Appendix E, we show that our results are largely unchanged when controlling for additional local controls. These include the number of COVID-19 cases and deaths per capita in the state at the time the respondent took the survey, the minimum distance from the centroid of the respondent's ZIP code to the closest SBA approved lender, the number of SBA approved lenders within 10 kilometers, and ZIP code level demographic controls. The appendix also repeats the above analysis, but controlling for baseline expectations about the future in the sub-sample of respondents that completed both the baseline and follow-up surveys. This is a smaller sample and estimates are less precise, but the table finds similar though smaller coefficients on PPP receipt.

\subsection{Discussion and conclusion}

Our results suggest that information frictions played an important role in determining differential access to PPP resources between smaller and larger businesses. These frictions might be associated with, for example, uncertainty about the eligibility criteria or the forgivable aspect of the loan. We argue that these frictions are more binding for small businesses for at least three reasons. First, firm sophistication (measured by years of education of the owner and firm type) 
is positively correlated with firm size, and lower sophistication could imply greater difficulties in accessing and processing information. Second, larger firms typically have more and better human resources (e.g. accountants or human resources departments), which also contributes to reducing the cost of acquiring information, and applying to the program. Third, there are fixed costs implied by the application process (e.g. finding a bank that will accept the application and acquiring appropriate documentation of payroll), which are more likely to be binding for smaller business. The "first-come, first-served" nature of the program magnifies the potential impacts of these frictions since a timely application was integral to quickly receiving a PPP loan.

The results also show that lower application rates, longer processing times, and ultimately less access to the programs may have had negative consequences for small firms. To the extent that small businesses struggle to re-hire laid-off workers (potentially due to increased unemployment benefits introduced by the CARES Act), the layoffs that have already occurred might be costly to reverse in the short- to mid-run. ${ }^{20}$ This by itself also potentially reduces the attractiveness of loans from the later stages of PPP (which are not covered in our survey), as payroll determines the size of the loan and how much of the loan can be forgiven. Moreover, uncertainty about what can be forgiven, and how firms will apply for forgiveness may have caused firms to not apply. When the PPP was initially launched, there were few details on how forgiveness worked, and the detailed rules were not posted until May 22nd, almost two months after the CARES Act was signed into law (the rules were then further amended in early June). The initial uncertainty, combined with changing guidance, may have distorted small business owners' beliefs about their eligibility and what the program actually provides.

Overall, our results show unequal access to program resources across firm size. Even though we cannot rule out all competing explanations, the results strongly indicate that information frictions, combined with the "first-come, first-served" nature of the PPP, played a central role in this inequality of access. Moreover, our results indicate that lack of access to PPP is associated with substantially worse outcomes for small businesses, such as greater layoffs and perceived probability of bankruptcy, and overall worse expectations about their businesses' recovery.

\footnotetext{
${ }^{20}$ While many layoffs may have been intended to be temporary (Alstadsæter et al., 2020), the increased UI benefits introduced as part of the CARES Act, may create additional challenges in re-hiring workers (Barrero et al., 2020).
} 


\section{References}

Adams-Prassl, Abi, Teodora Boneva, Marta Golin, and Christopher Rauh, "Inequality in the impact of the coronavirus shock: Evidence from real time surveys," 2020.

Alstadsæter, Annette, Bernt Bratsberg, Gaute Eielsen, Wojciech Kopczuk, Siem Markussen, Oddbjorn Raaum, and Knut Røed, "The First Weeks of the Coronavirus Crisis: Who Got Hit, When and Why? Evidence from Norway," NBER Working Paper, 2020, 27131.

Autor, David, David Cho, Leland D. Crane, Mita Goldar, Byron Lutz, Joshua Montes, William B. Peterman, David Ratner, Daniel Villar, and Ahu Yildirmaz, "An Evaluation of the Paycheck Protection Program Using Administrative Payroll Microdata," Working Paper, MIT July 2020.

Barrero, Jose Maria, Nick Bloom, and Steven J. Davis, "Covid-19 is Also a Reallocation Shock," Becker Friedman Institute Working Paper, 2020, 2020-59.

Barrios, John M. and Yael Hochberg, "Risk Perception Through The Lens of Politics in the Time of the COVID-19 Pandemic," Working Paper 27008, National Bureau of Economic Research 2020.

Bartik, Alexander W., Marianne Bertrand, Zoe Cullen, Edward L. Glaeser, Michael Luca, and Christopher Stanton, "How are small businesses adjusting to COVID-19? Early Evidence from a Survey," NBER working paper, 2020, 26989.

Beland, Louis-Philippe, Abel Brodeur, and Taylor Wright, "The Short-Term Economic Consequences of COVID-19: Exposure to Disease, Remote Work and Government Response," IZA DP No.13159, 2020.

Besley, Timothy and Stephen Coate, "Workfare versus welfare: Incentive arguments for work requirements in poverty-alleviation programs," The American Economic Review, 1992, $82(1), 249-261$.

Bettinger, Eric P., Bridget Terry Long, Philip Oreopoulos, and Lisa Sanbonmatsu, "The Role of Application Assistance and Information in College Decisions: Results from the H\&R Block FAFSA Experiment," The Quarterly Journal of Economics, 07 2012, 127 (3), 1205-1242. 
Bhargava, Saurabh and Dayanand Manoli, "Psychological frictions and the incomplete take-up of social benefits: Evidence from an IRS field experiment," American Economic Review, 2015, 105 (11), 3489-3529.

Cajner, Tomaz, Leland D. Crane, Ryan A. Decker, John Grigsby, Adrian HaminsPuertolas, Erik Hurst, Christopher Kurz, and Ahu Yildirmaz, "The U.S. Labor Market During the Beginning of the Pandemic Recession," Working Paper 2020-58, Becker Friedman Institute 2020.

Center for Disease Control, "Cases of Coronavirus Disease (COVID-19) in the U.S.," https: //www.cdc.gov/coronavirus/2019-ncov/cases-updates/cases-in-us.html 2020. Accessed: 2020-07-20.

Chetty, Raj, John N. Friedman, Nathaniel Hendren, and Michael Stepner, "How Did COVID-19 and Stabilization Policies Affect Spending and Employment? A New Real-Time Economic Tracker Based on Private Sector Data," Working Paper 27431, National Bureau of Economic Research 2020.

Coibion, Olivier, Yuriy Gorodnichenko, and Michael Weber, "Labor Markets During the COVID-19 Crisis: A Preliminary View," Working Paper 27017, National Bureau of Economic Research April 2020.

Cororaton, Anna and Samuel Rosen, "Public Firm Borrowers of the US Paycheck Protection Program," Working Paper, SSRN 2020.

Fairlie, Robert W, "The Impact of COVID-19 on Small Business Owners: Continued Losses and the Partial Rebound in May 2020," Working Paper 27462, National Bureau of Economic Research July 2020.

_ , "The Impact of Covid-19 on Small Business Owners: Evidence of Early-Stage Losses from the April 2020 Current Population Survey," Working Paper 27309, National Bureau of Economic Research June 2020.

Finkelstein, Amy and Matthew J Notowidigdo, "Take-up and targeting: Experimental evidence from SNAP," The Quarterly Journal of Economics, 2019, 134 (3), 1505-1556.

Granja, João, Christos Makridis, Constantine Yannelis, and Eric Zwick, "Did the Paycheck Protection Program Hit the Target?," Working Paper 2020-52, Becker Friedman Institute 2020 . 
Kahn, Lisa B., Fabian Lange, and David G. Wiczer, "Labor Demand in the Time of COVID-19: Evidence from Vacancy Postings and UI Claims," NBER Working Paper, 2020, 27061.

Zwick, Eric and James Mahon, "Tax Policy and Heterogeneous Investment Behavior," American Economic Review, 2017, 107 (1), 217-248. 
Table 1: PPP timing by firm characteristics

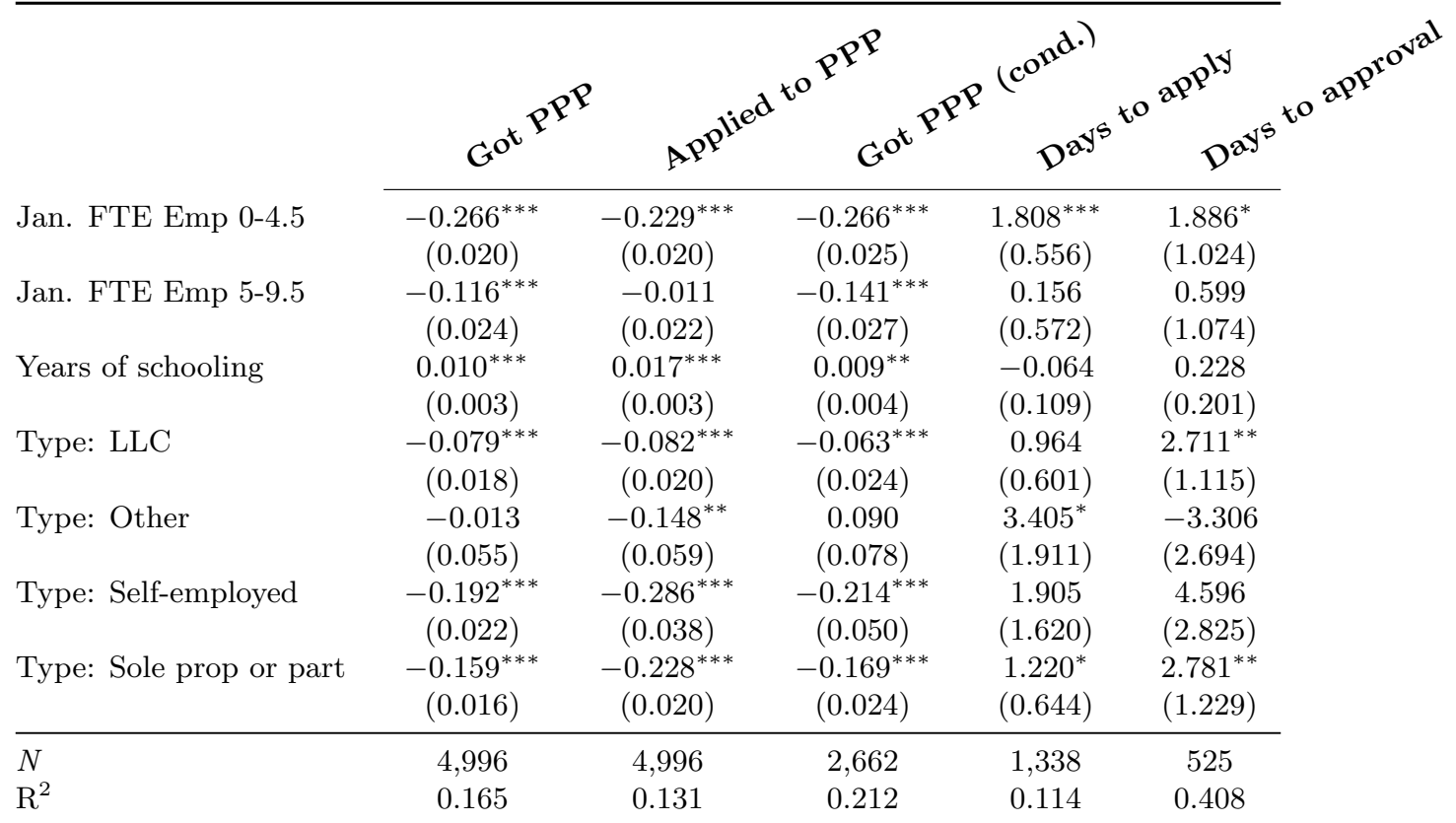

Note: ${ }^{* * *}$ Significant at the 1 percent level, ${ }^{* *}$ significant at the 5 percent level, and ${ }^{*}$ significant at the 10 percent level. The first four specifications control for the date the survey was taken. The final regression controls for the day the first PPP loan application was submitted and the week of the survey. All regressions also include controls for industry, age groups, and gender, but coefficients were largely not statistically significant nor large and are not displayed as they largely did not predict the outcomes. All regressions additionally control for state of residence. The omitted category for firm type is C-Corps and S-Corps. The omitted category for firm-size bins is firms with 10 to 50 FTE employees. Columns 4 and 5 have fewer observations as many respondents did not provide the dates of their application and approval. Alternative specifications of these results are included in Appendix E. These include a table replicating these results controlling for for additional state and ZIP code level characteristics, results controlling for baseline beliefs of the firms, and results separating firms with zero employees from firms with 0.5 -4.5 employees. 
Figure 1: Responses over time
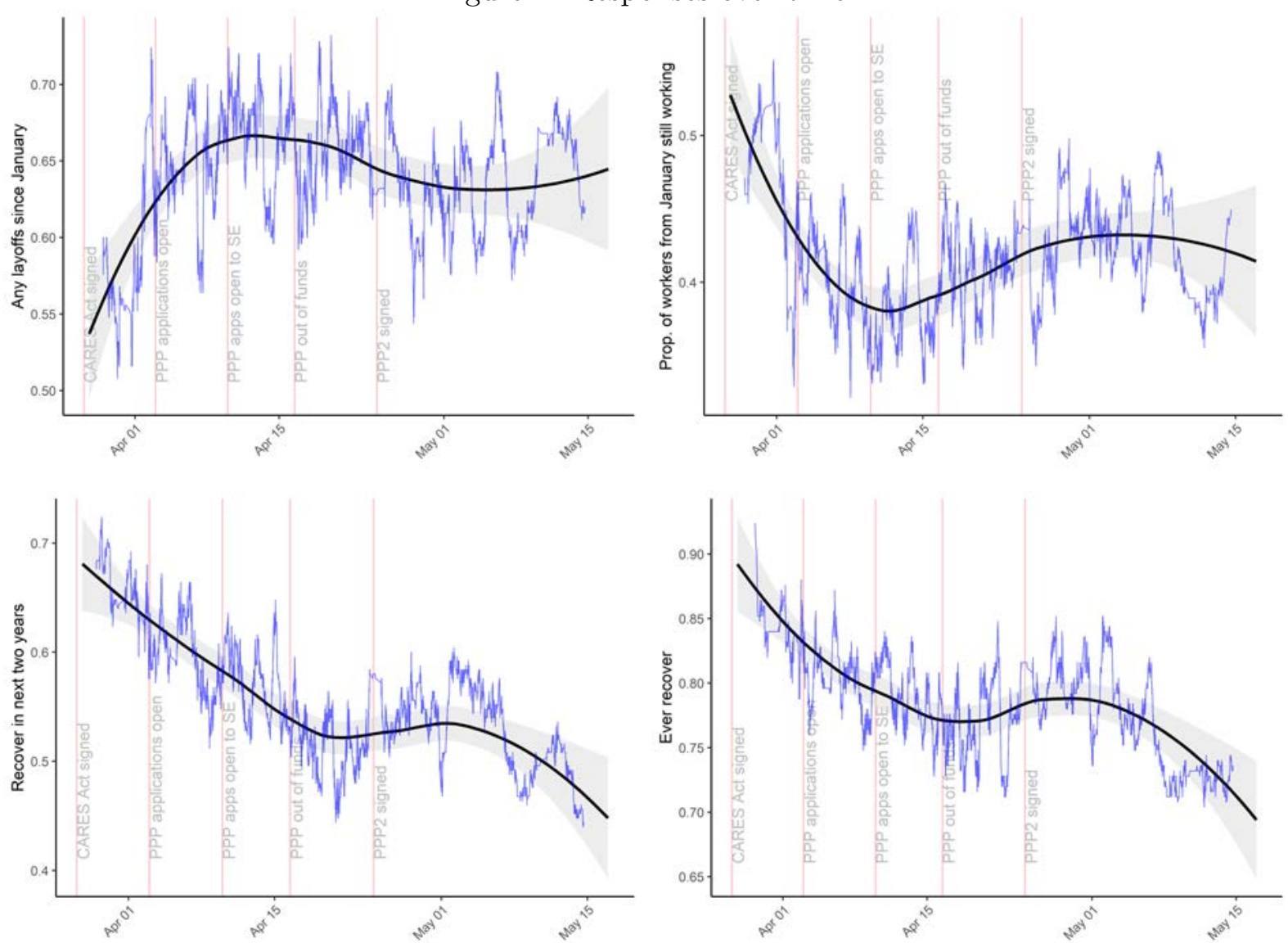

Note: The figure shows survey responses to key questions from March 28th, 2020 to May 16th, 2020. The black line is fit using locally weighted smoothing regression, with the grey region showing the $95 \%$ confidence interval. The blue line shows a centered moving average over 250 responses. The vertical red lines reference the dates of key events related to the Paycheck Protection Program. 
Figure 2: Are you aware of any federal or state programs that could help your business?
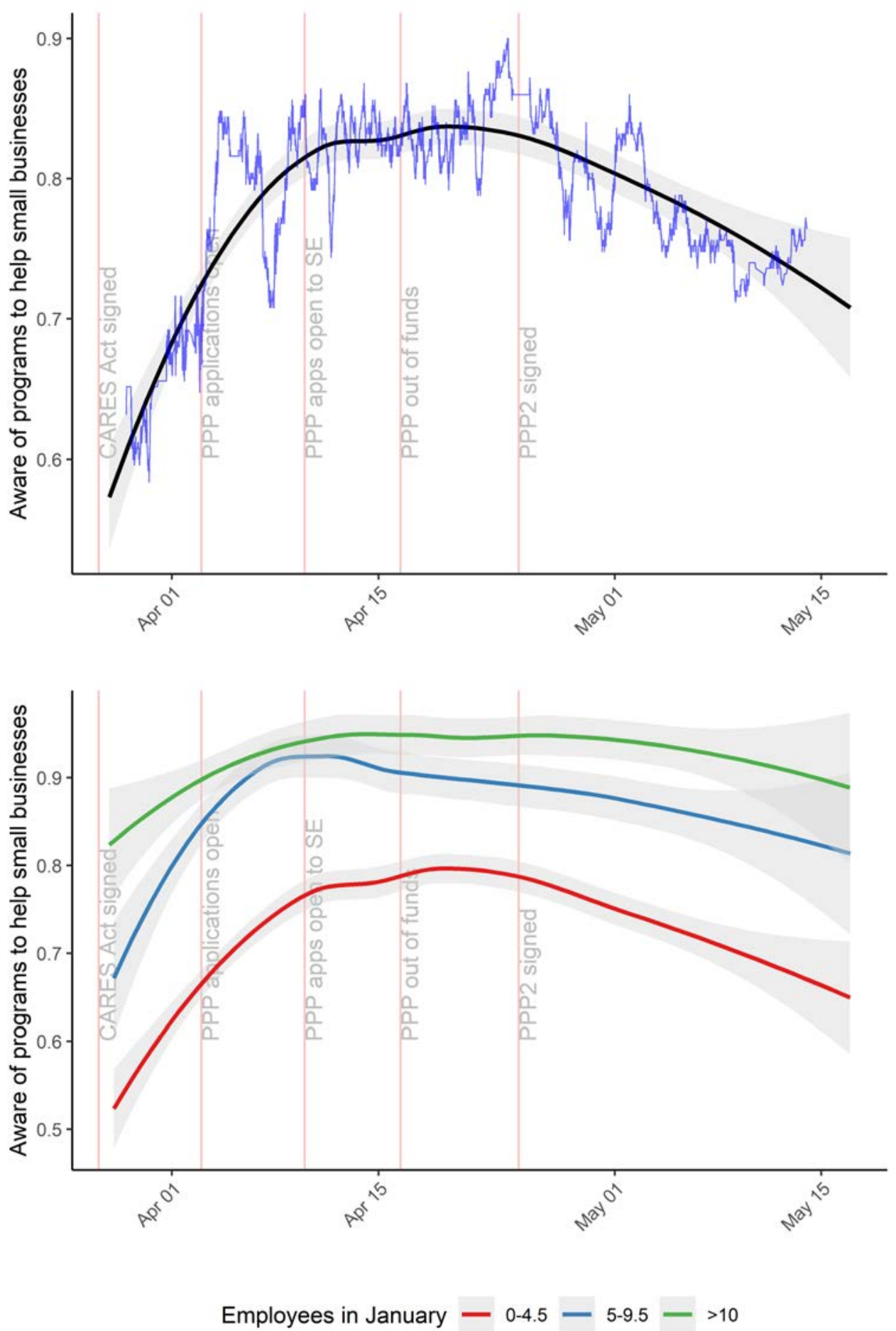

Note: In the top panel, the black line is fit using locally weighted smoothing regression, with the grey region showing the $95 \%$ confidence interval. The blue line shows a centered moving average over 250 responses. The bottom panel shows loess regression lines over time by business size bins based on the number of FTE employees in January, 2020. Estimates are based on the response to the question "Are you aware of any federal or state programs that could help your business during this crisis?" and thus may capture a combination of awareness of the program as well as comprehension of how the program works, who is eligible, and how to apply. 
Table 2: PPP loans and business outcomes

\begin{tabular}{|c|c|c|c|c|c|c|c|c|}
\hline \multirow[b]{3}{*}{$\mathrm{PPP}$} & \multicolumn{8}{|c|}{ Recover in next 2 years } \\
\hline & \multicolumn{2}{|c|}{ All } & \multicolumn{2}{|c|}{ 0-4.5 FTE } & \multicolumn{2}{|c|}{ 5-9.5 FTE } & \multicolumn{2}{|c|}{ 10-50 FTE } \\
\hline & $\begin{array}{c}0.080^{* * *} \\
(0.019)\end{array}$ & & $\begin{array}{c}0.114^{* * *} \\
(0.027)\end{array}$ & & $\begin{array}{c}0.086^{* *} \\
(0.039)\end{array}$ & & $\begin{array}{l}-0.010 \\
(0.044)\end{array}$ & \\
\hline PPP (cond) & & $\begin{array}{c}0.117^{* * *} \\
(0.022)\end{array}$ & & $\begin{array}{c}0.135^{* * *} \\
(0.032)\end{array}$ & & $\begin{array}{c}0.157^{* * *} \\
(0.047)\end{array}$ & & $\begin{array}{l}-0.008 \\
(0.057)\end{array}$ \\
\hline \multirow[t]{3}{*}{$N$} & 4,949 & 2,662 & 3,357 & 1,493 & 916 & 660 & 676 & 509 \\
\hline & \multicolumn{8}{|c|}{ Prob of closure or bankruptcy } \\
\hline & \multicolumn{2}{|c|}{ All } & \multicolumn{2}{|c|}{$0-4.5 \mathrm{FTE}$} & \multicolumn{2}{|c|}{ 5-9.5 FTE } & \multicolumn{2}{|c|}{ 10-50 FTE } \\
\hline $\mathrm{PPP}$ & $\begin{array}{c}-0.084^{* * *} \\
(0.009)\end{array}$ & & $\begin{array}{c}-0.085^{* * *} \\
(0.014)\end{array}$ & & $\begin{array}{c}-0.091^{* * *} \\
(0.019)\end{array}$ & & $\begin{array}{c}-0.078^{* * *} \\
(0.021)\end{array}$ & \\
\hline PPP (cond) & & $\begin{array}{c}-0.109^{* * *} \\
(0.011)\end{array}$ & & $\begin{array}{c}-0.107^{* * *} \\
(0.016)\end{array}$ & & $\begin{array}{c}-0.118^{* * *} \\
(0.023)\end{array}$ & & $\begin{array}{c}-0.104^{* * *} \\
(0.026)\end{array}$ \\
\hline \multirow[t]{3}{*}{$N$} & 4,949 & 2,662 & 3,357 & 1,493 & 916 & 660 & 676 & 509 \\
\hline & \multicolumn{8}{|c|}{ Current employment } \\
\hline & \multicolumn{2}{|c|}{ All } & \multicolumn{2}{|c|}{$0-4.5 \mathrm{FTE}$} & \multicolumn{2}{|c|}{$5-9.5 \mathrm{FTE}$} & \multicolumn{2}{|c|}{ 10-50 FTE } \\
\hline PPP & $\begin{array}{c}0.554^{* * *} \\
(0.168)\end{array}$ & & $\begin{array}{c}0.233^{* * *} \\
(0.070)\end{array}$ & & $\begin{array}{c}0.806^{* * *} \\
(0.216)\end{array}$ & & $\begin{array}{c}0.882 \\
(0.717)\end{array}$ & \\
\hline PPP (cond) & & $\begin{array}{c}0.548^{* * *} \\
(0.185)\end{array}$ & & $\begin{array}{c}0.255^{* * *} \\
(0.077)\end{array}$ & & $\begin{array}{c}0.856^{* * *} \\
(0.252)\end{array}$ & & $\begin{array}{c}0.848 \\
(0.880)\end{array}$ \\
\hline \multirow[t]{3}{*}{$N$} & 4,949 & 2,662 & 3,357 & 1,493 & 916 & 660 & 676 & 509 \\
\hline & \multicolumn{8}{|c|}{ Past layoffs } \\
\hline & A & & $0-4$ & FTE & $5-9$. & FTE & $10-5$ & FTE \\
\hline PPP & $\begin{array}{c}-0.086^{* * *} \\
(0.018)\end{array}$ & & $\begin{array}{c}-0.115^{* * *} \\
(0.027)\end{array}$ & & $\begin{array}{l}-0.057 \\
(0.038)\end{array}$ & & $\begin{array}{c}-0.068^{*} \\
(0.037)\end{array}$ & \\
\hline PPP (cond) & & $\begin{array}{c}-0.112^{* * *} \\
(0.021)\end{array}$ & & $\begin{array}{c}-0.137^{* * *} \\
(0.029)\end{array}$ & & $\begin{array}{c}-0.085^{*} \\
(0.044)\end{array}$ & & $\begin{array}{l}-0.059 \\
(0.045)\end{array}$ \\
\hline$N$ & 4,949 & 2,662 & 3,357 & 1,493 & 916 & 660 & 676 & 509 \\
\hline
\end{tabular}

Note: ${ }^{* * *}$ Significant at the 1 percent level, ${ }^{* *}$ significant at the 5 percent level, and ${ }^{*}$ significant at the 10 percent level. "PPP" is an indicator for if the business received a PPP loan while "PPP (cond)" is the same regression, but restricted to those who applied to the PPP program. The first two columns show results for the full sample, while the remaining columns show results conditional on firm size bins. All regressions control for a third order polynomial in the number of full-time employees in January, a third order polynomial in the number of part-time employees in January, the day of the week the survey was completed, state dummies, years of education dummies, gender, age group dummies, firm type, firm sector, and the date the survey was completed. See Appendix E for additional robustness results. These include a table replicating this analysis controlling for additional state and ZIP code level characteristics and a table replicating this analysis controlling for baseline beliefs. 


\section{A Appendix: Details on the Paycheck Protection Pro-}

\section{gram}

The Paycheck Protection Program (PPP) was established under the CARES Act to provide loans for small businesses impacted by COVID-19. These loans differ from previous Small Business Administration (SBA) loans because they do not require collateral or a credit check. Moreover, the loans may be fully forgiven if the money is spent on payroll, rent, utilities, or interest payments on business mortgages for an 8-week period (with a minimum of $75 \%$ to payroll). The first round of aid was available April 3 for small businesses and sole proprietorships. On April 10, independent contractors and self-employed individuals were also able to apply. The initial $\$ 350$ billion allocated for the program was exhausted as of April 16. The Paycheck Protection Program received a second round of funding from Congress and the Small Business Administration resumed accepting applicants on April 27. The program expired with funds remaining on June 30th, but was then extended, reopening to applications on July 7 th and is scheduled to remain open through August 8th.

The SBA posted its first Interim Final Rule that announced the implementation of the Coronavirus Aid, Relief, and CARES Act on April 2nd. Since then, the SBA has posted additional Interim Final Rules that supplement or change those previously posted. Updates have included additional guidance on on eligibility for: certain pledges of loans, certain electric cooperatives, student and seasonal workers, and other specific types of businesses. The Interim Final Rules also provides additional guidance on loan forgiveness. On June 5th, the Paycheck Protection Program Flexibility Act was signed into law that changed some aspects of the program. Under the new rules, $60 \%$ of forgivable expenses were required to be payroll. Borrowers were also given 24 weeks for which qualified expenses could be forgiven rather than 8 . The term of the loan was increased from two to five years, and exceptions were introduced that could allow some loans to be forgiven even if payroll was not fully restored.

\section{Eligibility}

In order to be eligible for the Paycheck Protection Program, the applicant or business impacted by COVID-19 must meet entity-specific criteria. Eligible applicants include: sole proprietors, independent contractors, and self-employed persons. Self-employed individuals must have been in operation no later than February 15, 2020, been an individual with self-employed income, have a principal place of residence in the U.S., and have filed or intends to file a 2019 Form 1040 
Schedule C.

Loan eligibility extends to any small business that meets the SBA's size standards or business with a NAICS Code that begins with 72 (as long as the location employs less than 500 per location). Additional eligible businesses that have 500 or more employees or that meet the SBA's industry size standard (if more than 500) include: non-profit organizations, veteran organizations, or Tribal business.

Applicants are not eligible for the PPP if: (1) they engage in any illegal activities under federal, state, or local law; (2) If an owner with $20 \%$ equity or more is incarcerated, on probation, on parole, or currently subject to any criminal charges; or has been convicted of a felony within the last five years; or (3) if the applicant, the applicant's co-owners, or any of the applicant's businesses received or guaranteed a loan from the SBA or other Federal agency, and that loan is currently delinquent within the last 7 years.

\section{Application Process}

In order to apply for the PPP, business owners must submit the application form with supplementary materials to existing SBA approved lenders or other FDIC insured lenders. On the application form, business owners are asked about whether they received any Economic Injury Disaster Loans, their number of employees, their average monthly payroll, and information on any co-owners holding at least $20 \%$ equity of the business. In addition to the form, applicants are asked to provide documentation on the number of full-time equivalent employees on their payroll and other costs, such as mortgage interest payments and rent. Business owners are not required to provide any personal guarantee or collateral, or prove that they were not able to receive credit elsewhere in order to apply for the PPP.

\section{Conditions of the Program}

The PPP offers loans to small business owners with a fixed interest rate of $1 \%$. All payments are deferred for the first six months, though borrowers are not penalized for prepayment. In the case that business owners default on their loans, the administration is barred from laying any

claims to theirs or their shareholders' assets. As aforementioned, the PPP allows borrowers to cover payroll costs, which includes salaries, retirement benefits, group health care benefits, rent, utilities, any mortgage or debt obligations, payments for vacation, parental, family, or medical leave, and allowances for dismissals.

While the PPP's coverage of payroll costs is broad, there are a few limitations. In particular, 
workers whose primary places of residence are outside of the U.S. cannot be included in the calculation of payroll costs, nor can independent contractors (who can instead apply for a PPP loan directly). Wages are also capped at $\$ 100,000$ for each employee. In addition, the PPP can only cover family and sick leave wages that are not eligible for credit under the Families First Coronavirus Response Act (FFCRA). ${ }^{21}$

The maximum PPP loan amount depends on three main factors: whether the business hires employees seasonally, whether it is new, and whether it has previously received an Economic Injury Disaster Loan. The first two factors impact the reference period for calculating payroll costs. Generally, the loan amount is capped at 2.5 times the average, monthly payroll costs during the last year. However, seasonal employees can choose to calculate their average, monthly payroll costs between February 15 and June 30, 2019. If a business is new (defined as not operating between February 15 and June 30, 2019), the reference time period for average, monthly payroll costs is between January 1 and February 29, 2020. If an applicant received an Emergency Injury Disaster Loan (EIDL) between January 31 and April 3, 2020, then any outstanding payments for the EIDL should be added to the loan amount. Any advance EIDL loan should be excluded from the calculation, as the advance does not need to be repaid. The total PPP loan amount is capped at $\$ 10$ million.

\section{Forgiveness}

Generally, all payroll costs covered by the loan may be forgiven, if wages are capped at $\$ 100,000$ per employee. For other purposes, such as rent, utilities, and mortgage interest payments, the maximum amount forgivable is $25 \%$ of payroll costs. However, the loan may not be forgiven if an owner reduced their full-time equivalent (FTE) workforce since February 15 or lowered wages originally below $\$ 100,000$ by more than $25 \%$ compared to the most recent quarter. With that said, borrowers who made such changes between February 15 and April 26, 2020, may be exempt from the reduction if they restore their employee numbers and/or wages by June 30, 2020.

\section{B Appendix: Survey details}

Participants were recruited via facebook ads targeted at business owners in the United States. Ads were targeted at people living in the US aged 25 or older, and targeted people who matched:

\footnotetext{
${ }^{21}$ The FFCRA provides fully refundable tax credits for sick and family leave wages if an employee is personally impacted by COVID-19.
} 
- Behaviors: Small business owners

- Employers: Business Owner

- Interests: Small Business

- Job title: Owner and Founder

Figure 3 provides a photo of the ad used for recruiting for the survey.

Figure 3: Facebook Ad used for recruitment

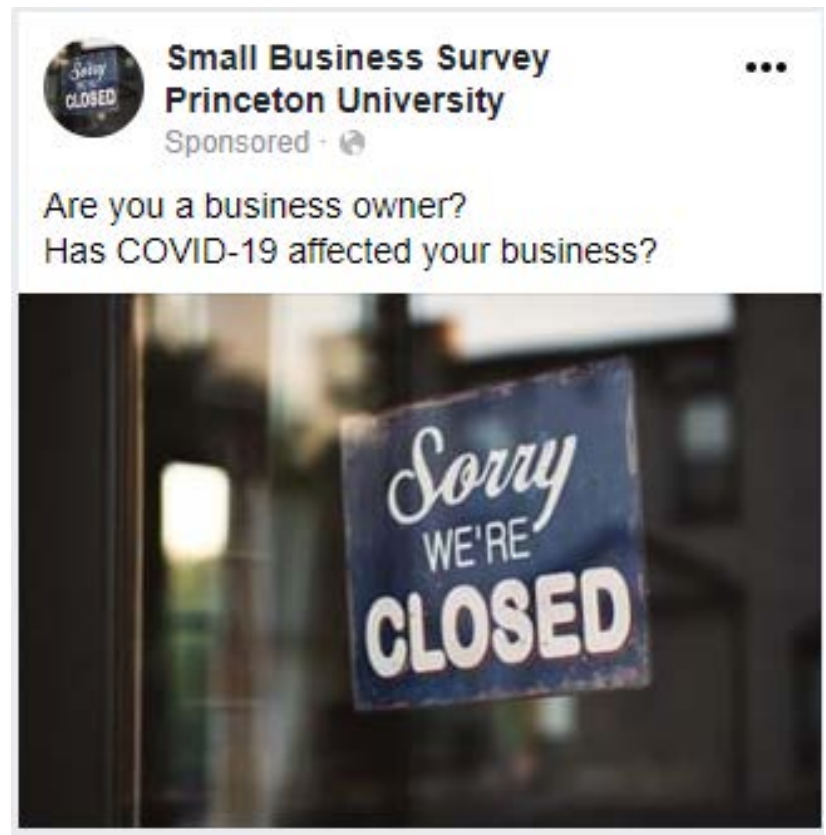

PRINCETONSURVEY.AZ1.QUA.

Small Business Survey

LEARN MORE

Help Princeton researchers und.

\section{B.1 Survey questions}

This subsection provides the three survey instruments used in this study:

- The baseline survey, which was used from March 28th through April 26th, 2020

- An extended baseline survey sued from April 27th through May 16th, 2020

- A follow-up survey which began on April 19th, 2020 for those completing the original baseline survey 


\section{Baseline Survey:}

Q1.1: The 2020 Small Business Survey has been explained to me. I know that I may refuse to participate or to stop the interview at any time without repercussions of any kind. I consent to participate:

Yes

$\square$ No

Q2.1: How many employees worked at the business you own in January 2020? Number of Full-time Employees:

Number of Part-time Employees:

Q2.2: Please enter the ZIP code of your business:

Q3.1: As of today, have you been required to lay off any employees in response to the current health crisis?

$\square$ Yes

$\square$ No

Q3.2: How many employees have you been required to lay off?

Number of Full-time Employees:

Number of Part-time Employees:

Q4.1: Do you think you will need to lay off any employees in the next 60 days?

Yes

$\square$ No

Q4.2: How many employees do you think you will need to lay off in the next 60 days? Number of Full-time Employees:

Number of Part-time Employees:

Q5.1: Do you think your business will fully recover within the next two years?

Yes

$\square$ No

Q5.2: How many months do you think this will take?

Q5.3: Do you think that your business will ever recover?

Yes

No

Q6.1: On a scale of $0-100$, what do you think the probability is that your business will file for bankruptcy OR go out of business in the next 6 months? 
Q7.1: Are you aware of any federal or state programs that could help your business during this crisis?
Yes
$\square$ No

Q7.2: Are you aware of any federal or state programs that could help your business with the following:

\begin{tabular}{|c|c|c|}
\hline $\begin{array}{c}\text { Programs That Cover } \\
\text { Your Employees' Wages }\end{array}$ & $\square$ No \\
\hline $\begin{array}{c}\text { Business Loans with } \\
\text { Subsidized Interest Rates }\end{array}$ & $\square$ No \\
\hline $\begin{array}{c}\text { Programs That Allow You } \\
\text { to Defer Rent, Mortgage, } \\
\text { or Loan Payments }\end{array}$ & $\square$ Yes \\
\hline $\begin{array}{c}\text { Programs That Cover } \\
\text { Your Rent }\end{array}$ & $\square$ Nos \\
\hline
\end{tabular}

Q8.1: State and federal governments are developed new policies to help businesses like yours. Would you like to be contacted by a nonprofit organization with information about federal problems that can help businesses like yours?

$\square$ Yes

$\square$ No

Q9.1: Researchers are still learning about how the COVID-19 crisis is affecting small businesses. Would you be willing to answer another survey in the future?

Yes

- No

Q10.1: To send you a follow-up survey, please enter your email:

Q11.1: To send you more information about federal programs that can help businesses like yours, please enter your contact information: 
Email:

Phone:

Q11.2: What is your preferred method of contact?

Email

$\square$ Phone

Q12.1: Many small businesses in the United States have been affected by the COVID19 Pandemic. Some types have been affected more than others. Can you share in your own words, what type of business you run, and how have you and your business been affected?

Q12.2: There has been a lot of discussion as to what small businesses need during this crisis. What can the state and federal government do to help your business weather the health and economic crisis over the next 6 months? 


\section{Extended Baseline Survey:}

Q1.1: The 2020 Small Business Survey has been explained to me. I know that I may refuse to participate or to stop the interview at any time without repercussions of any kind. I consent to participate:

Yes

$\square$ No

\section{Introduction}

Q2.1: How many employees worked at the business you own in January 2020?

Number of Full-time Employees:

Number of Part-time Employees:

Q2.2: Please enter the ZIP code of your business:

Q3.1: As of today, have you been required to lay off any employees in response to the current health crisis?

$\square$ Yes

$\square$ No

Q3.2: How many employees have you been required to lay off?

Number of Full-time Employees:

Number of Part-time Employees:

Q4.1: What describes best the current state of your business?

My business is open

My business is closed, but I plan to reopen

My business is permanently closed

Q4.2: If your business is open, is your business:

Open at full capacity

Open, but at reduced capacity (reduced hours or services)

Q4.3: If your business is closed and you plan to reopen, what best describes the reason for temporary closure?

$\square$ Lack of business

Closed by government order

Other; please specify:

Q4.4: If your business is permanently closed, are you currently:

I am employed at a new job 
I am unemployed

Other; please specify:

Q4.5: If your business is permanently closed and you are unemployed, are you actively looking for work?

Y Yes

$\square$ No

Q4.6: If you are unemployed, are you receiving government assistance? (e.g. unemployment insurance)

Yes

1 No

Q4.7: If you are employed at a new job, what type of employment is your new job?

Full-time

Part-time

$\checkmark$ Other; please specify:

\section{Layoff Plans}

Q4.8: Do you think you will need to lay off any employees in the next 60 days?

Yes

No

Q4.9: How many employees do you think you will need to lay off in the next 60 days? Number of Full-time Employees:

Number of Part-time Employees:

\section{Program Access for Closed Programs}

Q5.1: If your business is closed, are there any federal, state, or municipal programs that could have helped your business to survive?

$\square$ Yes

$\square \mathrm{No}$

Q5.2: If your business is closed and you believe there were no federal, state, or municipal programs that could have helped your business survive, please select the option that best applies:

I was not aware of any programs available to help small businesses

My business was not eligible for the existing programs

The available programs were not what I needed 
Other; please specify:

Q5.3: If your business is closed and you believe there were federal, state, or municipal program that could have helped your business, please select the option that best applies:

I did not know how to apply

I applied, but my application was rejected

I applied, but the aid not arrive in time

Other; please specify:

Q6.1: Please enter the amount of your total sales in March 2020 (or in your last month of operation):

\section{Recovery}

Q6.2: If your business is not closed, do you think your business will fully recover within the next two years?

$\square$ Yes

$\square$ No

Q6.2: If yes, how many months do you think this will take?

Q6.3: If not, do you think that your business will ever recover?

Yes

No

\section{Bankruptcy and Closure}

Q7.1: On a scale of 0-100, what do you think the probability is that your business will file for bankruptcy OR go out of business in the next 6 months?

Q8.1: Which bank, credit union or financial institution do you use the most for your business?

\section{Relief Access for Open Programs}

Q9.1: Are you aware of any federal or state programs that could help your business during this crisis?

$\square$ Yes

$\square$ No 
Q9.2: Are you aware of any federal or state programs that could help your business with the following:

\begin{tabular}{|c|c|c|}
\hline $\begin{array}{c}\text { Programs That Cover } \\
\text { Your Employees' Wages }\end{array}$ & $\square$ Yes \\
\hline $\begin{array}{c}\text { Business Loans with } \\
\text { Subsidized Interest Rates }\end{array}$ & $\square$ Yes \\
\hline $\begin{array}{c}\text { Programs That Allow You } \\
\text { to Defer Rent, Mortgage, } \\
\text { or Loan Payments }\end{array}$ & $\square$ Yes \\
\hline $\begin{array}{c}\text { Programs That Cover } \\
\text { Your Rent }\end{array}$ & $\square$ Yes & $\square$ No \\
\hline Other & $\square$ Yes & $\square$ No \\
\hline
\end{tabular}

Q9.3: If other, please specify what other federal or state program could help your business:

Q9.4: If you are not aware of an federal, state, or municipal programs that could help your business, are you unware of programs that could help your business because:

$\square$ I am not aware of any programs available to help small businesses

$\square$ My business does not qualify for the programs I am aware of

$\square$ Other; please specify:

Q10.1: Have you taken any steps towards searching or applying for any federal, state or municipal programs that could help your business?

\section{Yes}

$\square$ No

Q10.2: If you have taken steps toward searching or applying for any federal, state, or municipal programs, what best describes the steps you have taken to apply to programs that could help your small business: 
I have looked into programs, but haven't decided to apply

I have looked into programs and expect to begin the application soon

I have tried to apply for a program but have not been able to complete an application

I have completed an application

Other; please specify:

Q10.3: If you have tried to apply for a program but did not complete an application, what best describes your experience:

Not sure how to provide all the requested information

Couldn't get ahold of the bank or other institution

Other; please specify:

Q10.4: If you have completed an application, what best describes your experience:

I have not heard back

My application was rejected

I was notified that funds are no longer available

My application was accepted and approved

Other; please specify:

Q10.5: If you have begun or completed an application, was your application to any of the following programs?

The Paycheck Protection Program (PPP)

The Economic Injury Disaster Loan Program (EIDL)

Other; please specify:

Q11.1: If you applied to the Paycheck Protection Program (PPP), when did you first try to apply to the Paycheck Protection Program (PPP) that opened applications for small businesses on April 3, 2020?

Q11.2: If you applied to the PPP, did you apply again after?

Yes

No

Q11.3: If so, when did you last apply to the Paycheck Protection Program (PPP)? (mm/dd/yyyy):

Q11.4: If your application for the Paycheck Protection Program (PPP) was accepted and approved, what was the date? (mm/dd/yyyy): 
Q12.1: If you applied to the Economic Injury Disaster Loan Program (EIDL), when did you first try to apply to the Economic Injury Disaster Loan Program (EIDL)? (mm/dd/yyyy):

Q12.2: If your application for the Paycheck Protection Program (PPP) was accepted and approved, what was the date? (mm/dd/yyyy):

Q13.1: If you applied for a program, was your application through your primary bank, credit union, or financial institution?

Yes

No

Q13.2: If you applied for a program, did you also try to apply through a different bank, credit union, or financial institution other than your primary one?

Yes

$\square$ No

Q14.1: Which banks, credit unions, or financial institutions did you try to apply through other than your primary? Please write each one:

Q14.2: If you applied, please tell us in your own words about your experience with applying:

Q15.1. If you have not applied, what best describes your current situation:

I expect to apply in the future

I am still unsure if I will apply or not

I do not plan on applying in the future

Q15.2: If you are not planning to apply in the future, why is that?

I don't need assistance

The types of programs available are not what my business needs

I am not eligible

I don't think I will get support even if I apply

Other; if other, please explain: 
Q16.1: Have government support policies in response to the COVID-19 crisis helped your business:

\begin{tabular}{|c|c|c|}
\hline Not lay off workers & $\square$ Yes & $\square$ No \\
\hline Maintain your income & $\square$ Yes & $\square$ No \\
\hline $\begin{array}{c}\text { Maintain the income of } \\
\text { your workers }\end{array}$ & $\square$ Yes & $\square$ No \\
\hline
\end{tabular}

Q17.1: Think of all the revenue your business could make in the six months between March and September 2020 if it stays in business. On a scale of 0-100, what is your best guess for the percent of revenue that will be lost to your business in the six months between March and September 2020 because of COVID-19?

\section{Contact}

Q18.1: State and federal governments are developed new policies to help businesses like yours. Would you like to be contacted by a nonprofit organization with information about federal problems that can help businesses like yours?

Yes

$\square$ No

Q18.2: If yes, to send you more information about federal programs that can help businesses like yours, please enter your contact information:

Email:

Phone:

Q18.3: What is your preferred method of contact?

\section{Email}

Phone

Q19.1: Researchers are still learning about how the COVID-19 crisis is affecting small businesses. Would you be willing to answer another survey in the future?

Yes

No

Q19.2: To send you a follow-up survey, please enter your email: 


\section{Information About You}

We would like to know a little bit more about you, if you are willing to answer.

Q20.1: What is the highest educational level you have achieved?

Less than high school

High school graduate

Some college

2 year college degree

4 year college degree

$\square$ Professional degree

$\square$ Master's Degree

$\square$ Doctorate

Q20.2: What is your sex?

Male

Female

Q20.3: What is your age group?

$18-24$

25-34

34-49

$50+$

\section{Information About Your Business}

We would like to know a little bit more about your current or former business, if you are willing to answer.

Q21.1: Which sector best describes your current or previous activity?

Retail

Manufacturing

Services

Agriculture

Construction

$\square$ Other; if other, please explain:

Q21.2: What year did you first open your business?

Q21.3: Which type of small business do you or did you own? 
$\square$ Sole proprietor

$\square$ Independent contractor

$\square$ Partnership

$\square$ C-Corp

$\square$ S-Corp

$\square$ LLC

$\square$ Self-employed individual

$\square$ Non-profit

$\square$ Other; if other, please explain:

$\square$ I am not sure

For the study, it is helpful to track the businesses that answer the survey. For this purpose, it would be helpful to know a few things about the business. These answers are not required to be a useful participant in the study and will be treated as strictly confidential. These responses will be only used for the purpose of studying how the COVID-19 crisis is affecting small businesses.

Q22.1 Name of business:

Q22.2 Business address: 


\section{Government Responses}

Q23.1 Do you think that the government's response to the COVID-19 crisis is appropriate regarding:

\begin{tabular}{|c|c|c|}
\hline $\begin{array}{c}\text { Social distancing measures } \\
\text { (e.g. non-essential } \\
\text { business closures) }\end{array}$ & $\square$ Yes & No \\
\hline $\begin{array}{c}\text { Economic policies to help } \\
\text { workers }\end{array}$ & $\square$ Yes & $\square$ No \\
\hline $\begin{array}{c}\text { Economic policies to help } \\
\text { small businesses }\end{array}$ & $\square$ Yes \\
\hline $\begin{array}{c}\text { Economic policies to help } \\
\text { large businesses }\end{array}$ & $\square$ Yes & $\square$ No \\
\hline
\end{tabular}

Q23.2: Are there currently any mandated business closures in your area?

Yes

$\square$ No

Q23.3: If yes, when do you think the government should lift mandated business closures?

Within two weeks

Within a month

Within two months

Once the crisis is over

Q23.4: If there are no mandated business closures, were there in the past?

Yes, but they were lifted too soon

$\square$ Yes, but there were lifted at the right time

$\square$ No, but there should have been

$\square$ No, because it was not needed 
Q24.1: Do you think the reaction of your country's government to the current coronavirus outbreak is appropriate, too extreme, or not sufficient?

The reaction is much too extreme

$\square$ The reaction is somewhat too extreme

$\square$ The reaction is appropriate

$\square$ The reaction is somewhat insufficient

$\square$ The reaction is not at all sufficient

Q25.1: Many small businesses in the United States have been affected by the COVID19 Pandemic. Some types have been affected more than others. Can you share in your own words, what type of business you run, and how have you and your business been affected?

Q25.2: There has been a lot of discussion as to what small businesses need during this crisis. What can the state and federal government do to help your business weather the health and economic crisis over the next 6 months? 


\section{Follow-up Survey:}

Q1.1: The 2020 Small Business Survey has been explained to me. I know that I may refuse to participate or to stop the interview at any time without repercussions of any kind. I consent to participate:

Yes

$\square \mathrm{No}$

\section{Introduction}

Q2.1: What describes best the current state of your business?

My business is open

$\square$ My business is closed but I plan to re-open

$\square$ My business is permanently closed

Q2.2: Is your business:

$\square$ Open at full-capacity

$\square$ Open but at reduced capacity (reduced hours or services)

Q2.3: What best describes the reason for temporary closure?

$\square$ Lack of business

$\square$ Closed by government order

$\square$ Other; if other, please explain:

Q2.4: Are you currently:

I am employed at a new job

$\square$ I am unemployed

$\square$ Other; if other, please explain:

Q2.5: Are you actively looking for work?

Yes

No

Q3.1: Are you receiving government assistance? (e.g. unemployment insurance) Yes

No

Q4.1: What type of employment is your new job?

Full-time 
Part-time

Other; if other, please explain:

Q4.2: Is this new job:

Formal

Informal

\section{Size}

Q5.1: How many people are currently employed at your business?

Number of Full-time Employees:

Number of Part-time Employees:

Q5.2: How many of these employees are informal?

Number of Informal Full-time Employees:

Number of Informal Part-time Employees:

\section{Contract/Informal Workers}

Q5.3: How many independent contractors currently work for your business?

Number of Full-time Contractors:

Number of Part-time Contractors:

Q5.4: How many independent contractors worked for your business in January 2020?

Number of Full-time Contractors:

Number of Part-time Contractors:

Q5.5: How many informal workers worked for your business in January 2020?

Number of Informal Full-time Employees:

Number of Informal Part-time Employees:

\section{Layoff Plans}

Q6.1: Do you think you will need to lay off any employees in the next 60 days?

Yes

No

Q6.2: How many employees do you think you will need to lay off in the next 60 days? Number of Full-time Employees:

Number of Part-time Employees:

\section{Relief Program Access Shutdown}

Q7.1: Are there any federal, state, or municipal programs that could have helped your business to survive?

Yes

No

Q7.2: Please select the option that best applies: 
I was not aware of any programs available to help small businesses

My business was not eligible for the existing programs

The available programs were not what I needed

Other; if other, please explain:

Q7.3: If you were familiar with a program, why did you not apply?

I did not know how to apply

I applied, but my application was rejected

I applied, but the aid did not arrive in time

Other; if other, please explain:

Q8.1: Please enter the amount of your total sales in March 2020 (or in your last month of operation):

\section{Recovery}

Q9.1: Do you think that your business will recover within the next two years?

Yes

$\square$ No

Q9.2: If so, how many months do you think this will take:

Q9.3: Do you think that your business will ever recover?

Yes

$\square$ No

\section{Bankruptcy and Closure}

Q10.1: On a scale of $0-100$, what do you think the probability is that your business will file for bankruptcy OR go out of business in the next 6 months?

Q11.1: Please write the name of the bank, credit union, or financial institution you use most for your business:

\section{Relief Program Access Open}

Q12.1: Are you aware of any federal or state programs that could help your business during this crisis?

$\square$ Yes

$\square$ No

Q12.2: Are you aware of any federal or state programs that could help your business with the following: 


\begin{tabular}{|c|c|c|}
\hline $\begin{array}{c}\text { Programs That Cover } \\
\text { Your Employees' Wages }\end{array}$ & $\square$ Yes \\
\hline $\begin{array}{c}\text { Business Loans with } \\
\text { Subsidized Interest Rates }\end{array}$ & $\square$ Yes \\
\hline $\begin{array}{c}\text { Programs That Allow You } \\
\text { to Defer Rent, Mortgage, } \\
\text { or Loan Payments }\end{array}$ & $\square$ Yes \\
\hline $\begin{array}{c}\text { Programs That Cover } \\
\text { Your Rent }\end{array}$ & $\square$ No \\
\hline Yes & $\square$ No \\
\hline Other & $\square$ Yes & $\square$ \\
\hline
\end{tabular}

Q12.3: If you know, please specify what other federal or state program could help your business:

Q12.4: If you are unaware of programs that could help your business, is it because:

I am not aware of any programs available to help small businesses

My business does not qualify for the programs I am aware of

Other; if other, please explain:

Q13.1: Have you taken any steps towards searching or applying for any federal, state, or municipal programs that could help your business?

$\square$ Yes

$\square$ No

Q13.2: If applicable, what best describes the steps you have taken to apply to programs that could help your small business:

$\square$ I have looked into programs but haven't decided to apply

$\square$ I have looked into programs and expect to begin the application soon

$\square$ I have tried to apply for a program but have not been able to complete an application

$\checkmark$ I have completed an application 
Other; if other, please explain:

Q13.3: If applicable, what best describes your experience with applying:

Not sure how to provide all the requested information

Couldn't get ahold of the bank or other institution

Other; if other, please explain:

Q13.4: If applicable, what best describes the outcome of your application?

I have not heard back

My application was rejected

I was notified that funds are no longer available

My application was accepted and approved

Other; if other, please explain:

Q13.5: If applicable, was your application to any of the following programs:

The Paycheck Protection Program (PPP)

The Economy Injury Disaster Loan Program (EIDL)

Other; if other, please explain:

Q14.1: When did you first try to apply to the program (YYYY-MM-DD): [Note: question added on 4/26/2020]

Q14.2: When did you hear back from your application (YYYY-MM-DD): [Note: question added on 4/26/2020]

Q14.3: Was your application through your primary bank, credit union, or financial institution?

Yes

No

Q14.4: Did you also try to apply through a different bank, credit union, or financial institution other than your primary one?

Yes

$\square$ No

Q14.5: If so, which banks, credit unions, or financial institutions did you try to apply through other than your primary? Please specify each one:

Q14.6: Please tell us in your own words about your experience with applying:

Q14.7: What best describes your current situation:

I expect to apply in the future 
am still unsure if I will apply or not

I do not plan on applying in the future

Q14.8: If applicable, why are you not planning to apply in the future?

I don't need assistance

The types of programs available are not what my business needs

$\square$ I am not eligible

$\square$ I don't think I will get support even if I apply

$\square$ Other; if other, please explain:

Q15.1: Have government support policies in response to the COVID-19 crisis helped your business:

\begin{tabular}{|c|c|c|}
\hline Not lay off workers & $\square$ Yes & $\square$ No \\
\hline Maintain your income & $\square$ Yes & $\square$ No \\
\hline $\begin{array}{c}\text { Maintain the income of } \\
\text { your workers }\end{array}$ & $\square$ Yes & $\square$ No \\
\hline
\end{tabular}

Q16.1: On a scale of 0-100, what is your best guess for the percent of revenue that will be lost to your business in the six months between March and September 2020 because of COVID-19?

\section{Information About You}

We would like to know a little bit more about you, if you are willing to answer.

Q17.1: What is the highest educational level you have achieved?

Less than high school

High school graduate

Some college

$\square 2$ year college degree

4 year college degree

Professional degree 
Master's Degree

$\square$ Doctorate

Q17.2: What is your sex?

$\checkmark$ Male

$\square$ Female

Q17.3: What is your age group?

$\square$ 18-24

$\square 25-34$

$\square$ 34-49

$\square 50+$

\section{Information About Your Business}

We would like to know a little bit more about your business, if you are willing to answer.

Q18.1: Which sector best describes your current or previous activity?

$\square$ Retail

$\square$ Manufacturing

$\square$ Services

$\square$ Agriculture

$\square$ Construction

$\square$ Other; if other, please explain:

Q18.2: What year did you first open your business?

Q18.3: Which type of small business do you own or did you previously operate?

$\square$ Sole proprietor

$\square$ Independent contractor

$\square$ Partnership

$\square$ C-Corp

$\square$ S-Corp

$\square$ LLC

$\square$ Self-employed individual

$\square$ Non-profit

$\square$ Other; if other, please explain: 
I am not sure

Q18.4: Does your business have:

\begin{tabular}{|c|c|c|}
\hline Tax registration number & $\square$ Yes & $\square$ No \\
\hline $\begin{array}{c}\text { Municipal and/or state } \\
\text { license }\end{array}$ & $\square$ No \\
\hline Other & $\square$ Yes & $\square$ No \\
\hline
\end{tabular}

Q18.5: Is your business informal?
Yes

- No

$\square$ Other; if other, please explain:

For the study, it is helpful to track the businesses that answer the survey. For this purpose, it would be helpful to know a few things about the business. These answers are not required to be a useful participant in the study and will be treated as strictly confidential. These responses will be only used for the purpose of studying how the COVID-19 crisis is affecting small businesses.

Q19.1: Name of business:

Q19.2: Business address:

Q19.3: Business ID number: 
Government Response Questions

Q20.1: Do you think that the government's response to the COVID-19 crisis is appropriate regarding:

\begin{tabular}{|c|c|c|}
\hline $\begin{array}{c}\text { Social distancing measures } \\
\text { (e.g. non-essential } \\
\text { business closures) }\end{array}$ & $\square$ Yes & $\square$ No \\
\hline $\begin{array}{c}\text { Economic policies to help } \\
\text { workers }\end{array}$ & $\square$ Yes & $\square$ No \\
\hline $\begin{array}{c}\text { Economic policies to help } \\
\text { small businesses }\end{array}$ & $\square$ Yes & $\square$ No \\
\hline $\begin{array}{c}\text { Economic policies to help } \\
\text { large businesses }\end{array}$ & $\square$ Yes & \\
\hline
\end{tabular}

Q21.1: Are there currently any mandated business closures in your area?

$\square$ Yes

No

Q21.2: If yes, when do you think the government should lift mandated business closures?

Within two weeks

Within a month

$\square$ Within two months

$\square$ Once the crisis is over

Q21.3: If there are no mandated business closures, were there in the past?

Yes, but they were lifted too soon

$\square$ Yes, but there were lifted at the right time

$\square$ No, but there should have been

$\square$ No, because it was not needed 
Q21.4: Do you think the reaction of your country's government to the current coronavirus outbreak is appropriate, too extreme, or not sufficient?

$\square$ The reaction is much too extreme

$\square$ The reaction is somewhat too extreme

$\square$ The reaction is appropriate

$\square$ The reaction is somewhat insufficient

$\square$ The reaction is not at all sufficient

Q22.1: Can you share in your own words, how have you and your business been affected since the initial survey date?

Q22.2: In your opinion, which government programs have helped, or are likely to help, your business handle this health and economic crisis over the next 6 months? 


\section{Appendix: Details on survey respondents}

This section first provides details on the number of survey respondents over time, the geographic distribution of respondents across the United States, and summary statistics for key variables.

Second, this section compares the distribution of size and state of respondents to the distribution of firms in the 2017 Census of US Businesses. The Census of US Businesses data is restricted to firms with fewer than 500 employees. Figure 5 compares the distribution of respondent by size bin in our sample compared to firms in the 2017 Census of US Businesses. Figure 6 shows the relative distribution of responses compared to firms with fewer than 500 employees in each state. New England, the upper mid-west, and the Northwest are somewhat over-represented in the survey relative to the number of firms with fewer than 500 employees in each state, and California and the south are somewhat under-represented.

Third, this section compares two comparable questions from our survey to the Census Small Business Pulse Survey. The Pulse survey was a weekly survey of small businesses started on April 26th and run for nine week. The target population for the Census Pulse Survey was all nonfarm, single-location employer businesses 499 or less employees and receipts of $\$ 1,000$ or more in the 50 states, District of Columbia, and Puerto Rico and were drawn from the Business Register. Using this data, Figure 7 compares the proportion of respondents in our survey and the Pulse Survey who reported getting a PPP loan by firm size and week. Overall, the trends appear similar, though our survey reports slightly lower rates. This could be due to differential selection into our sample, or that the Pulse survey is drawn from the Business Registry and will miss non-employer establishments, such as the self-employed.

Figure 8 repeats the comparison above, but studying on if the businesses expect to ever recover. The question used from the Census Pulse Survey was either "I do not believe this business will return to its usual level of operations." or "I do not believe this business will return to its normal level of operations relative to one year ago", then subtracted from one to align with the question in our surveys. Here, the gaps between the survey are somewhat larger, though all show similar downward trends in May. The gap may indicate that we are reaching a more badly hit portion of the population, but may also come from (1) different constructions of the questions or (2) that the Pulse survey is drawn from the Business Registry and will miss non-employer establishments, such as the self-employed. 
Table 3: Valid survey responses by day

\begin{tabular}{cccc}
\hline Date & $\mathrm{N}$ & Date & $\mathrm{N}$ \\
\hline $2020-03-28$ & 147 & $2020-04-22$ & 352 \\
$2020-03-29$ & 173 & $2020-04-23$ & 251 \\
$2020-03-30$ & 161 & $2020-04-24$ & 52 \\
$2020-03-31$ & 167 & $2020-04-25$ & 243 \\
$2020-04-01$ & 639 & $2020-04-26$ & 197 \\
$2020-04-02$ & 758 & $2020-04-27$ & 376 \\
$2020-04-03$ & 530 & $2020-04-28$ & 198 \\
$2020-04-04$ & 425 & $2020-04-29$ & 268 \\
$2020-04-05$ & 193 & $2020-04-30$ & 324 \\
$2020-04-06$ & 396 & $2020-05-01$ & 261 \\
$2020-04-07$ & 451 & $2020-05-02$ & 265 \\
$2020-04-08$ & 462 & $2020-05-03$ & 200 \\
$2020-04-09$ & 459 & $2020-05-04$ & 189 \\
$2020-04-10$ & 360 & $2020-05-05$ & 222 \\
$2020-04-11$ & 418 & $2020-05-06$ & 203 \\
$2020-04-12$ & 368 & $2020-05-07$ & 156 \\
$2020-04-13$ & 322 & $2020-05-08$ & 97 \\
$2020-04-14$ & 282 & $2020-05-09$ & 118 \\
$2020-04-15$ & 362 & $2020-05-10$ & 28 \\
$2020-04-16$ & 462 & $2020-05-11$ & 88 \\
$2020-04-17$ & 472 & $2020-05-12$ & 103 \\
$2020-04-18$ & 501 & $2020-05-13$ & 94 \\
$2020-04-19$ & 440 & $2020-05-14$ & 59 \\
$2020-04-20$ & 418 & $2020-05-15$ & 61 \\
$2020-04-21$ & 389 & $2020-05-16$ & 44 \\
\hline
\end{tabular}

Note: Figure shows number of valid survey responses by day. 
Figure 4: Distribution of surveys across the United States

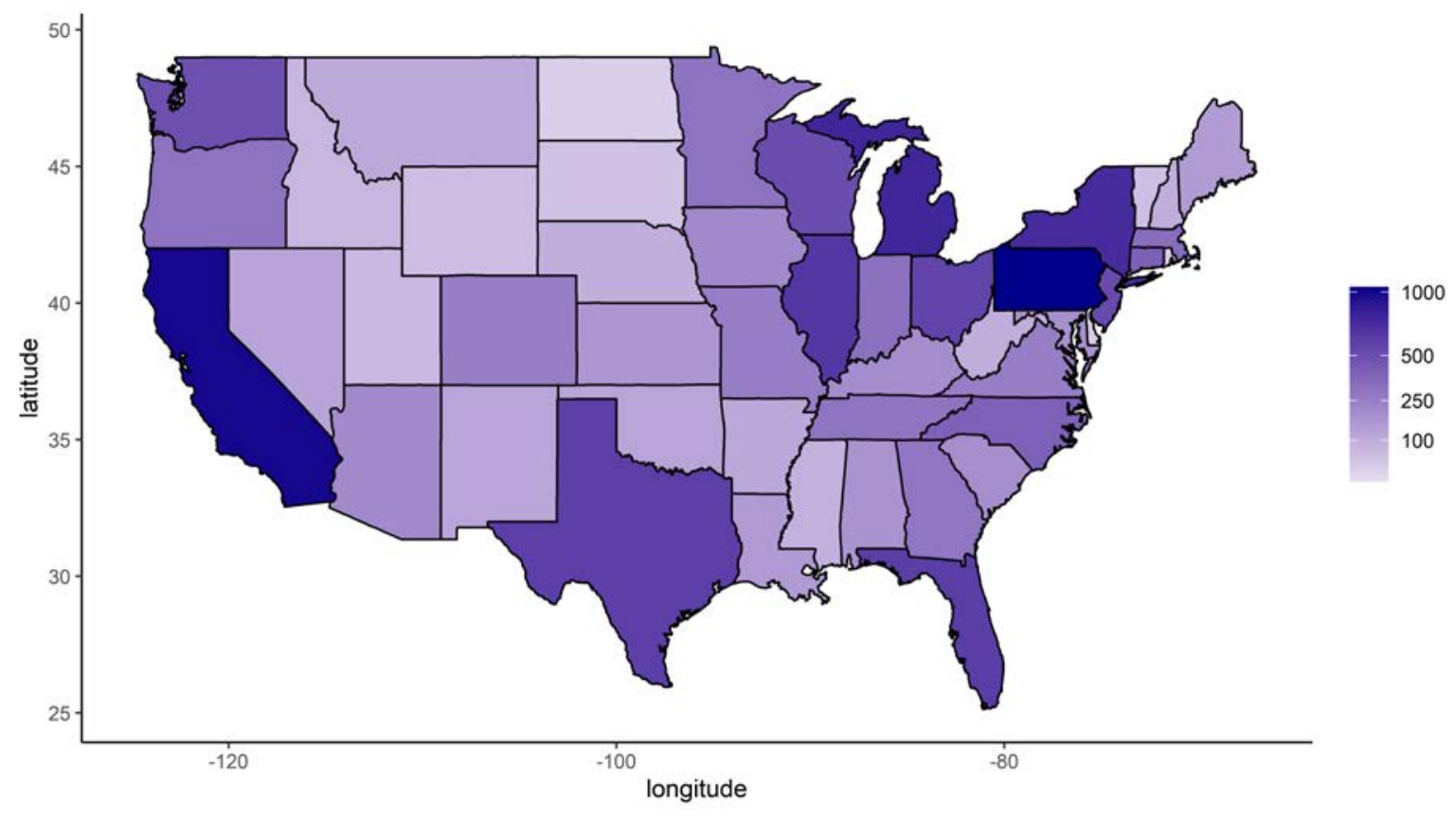

Note: Figure shows number of valid survey responses by state. 


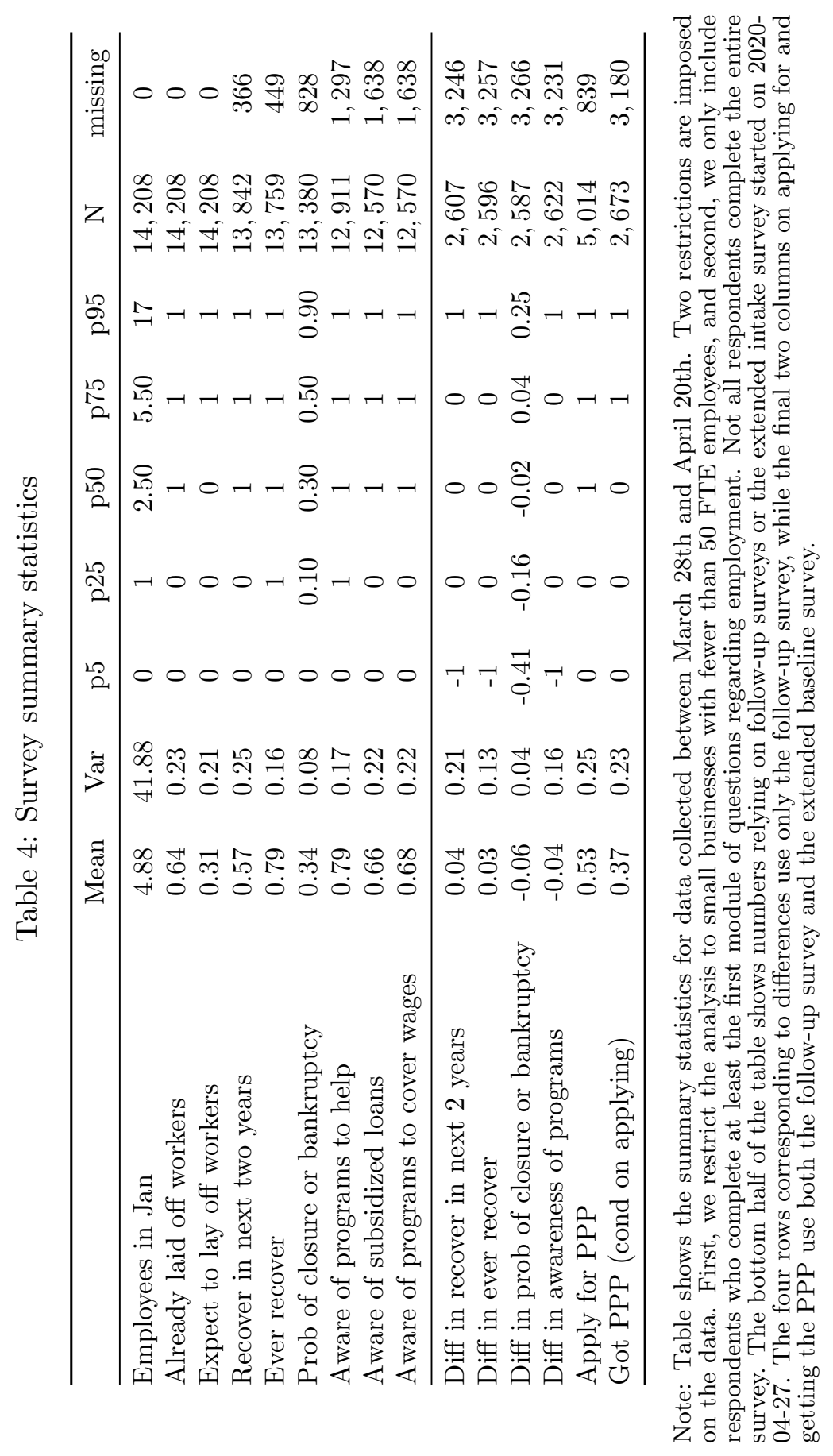


Figure 5: Firm size distribution: survey vs. Census

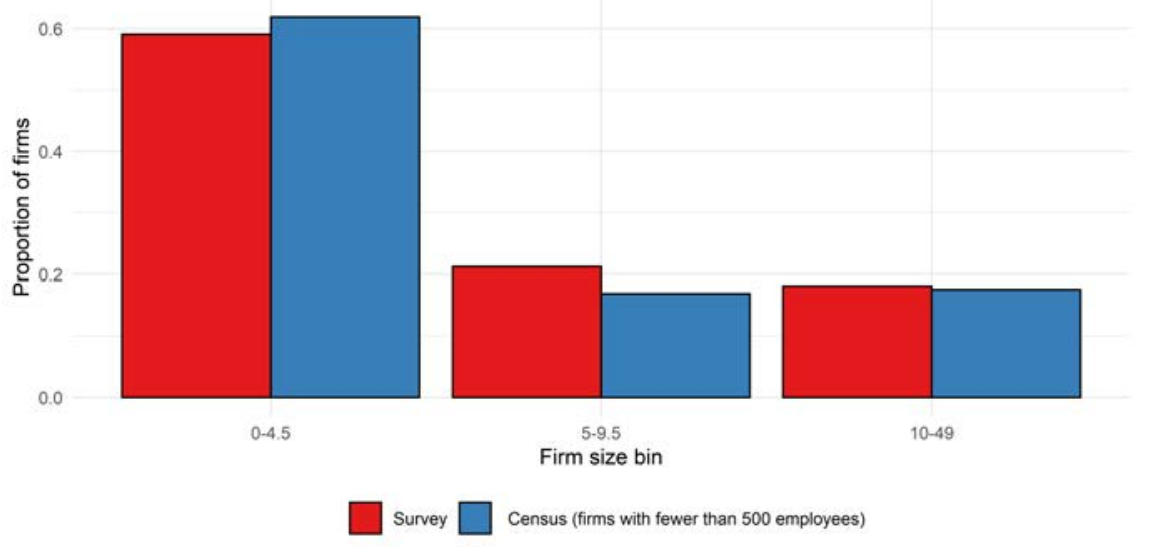

Note: Figure shows the share of firms with fewer than 500 employees in each employment category in the 2017 Census of US Businesses (in blue) and the survey respondents (in red).

Figure 6: Firm state distribution: survey vs. Census

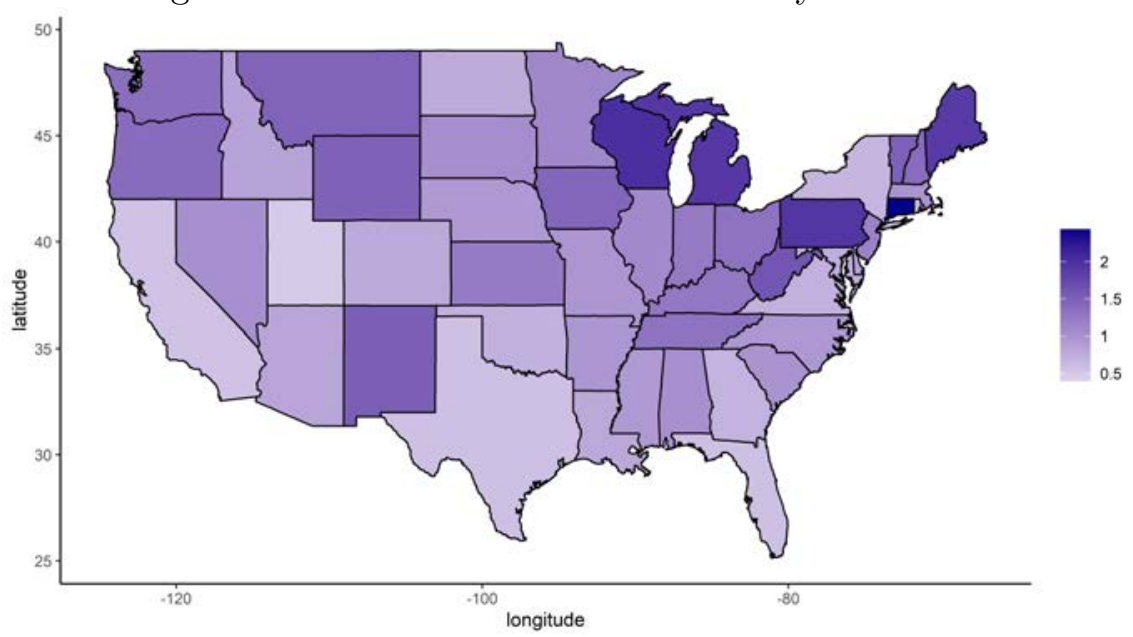

Note: The map shows the the the proportion of survey respondents from each state divided by the proportion of firms with fewer than 500 employees from each state (using data from the 2017 Census of US Businesses). States with values above 1 are over-represented in the survey, while states with values below 1 are under-represented. 
Figure 7: Comparing proportion of firms who received PPP loans (data vs. Census Pulse Survey)

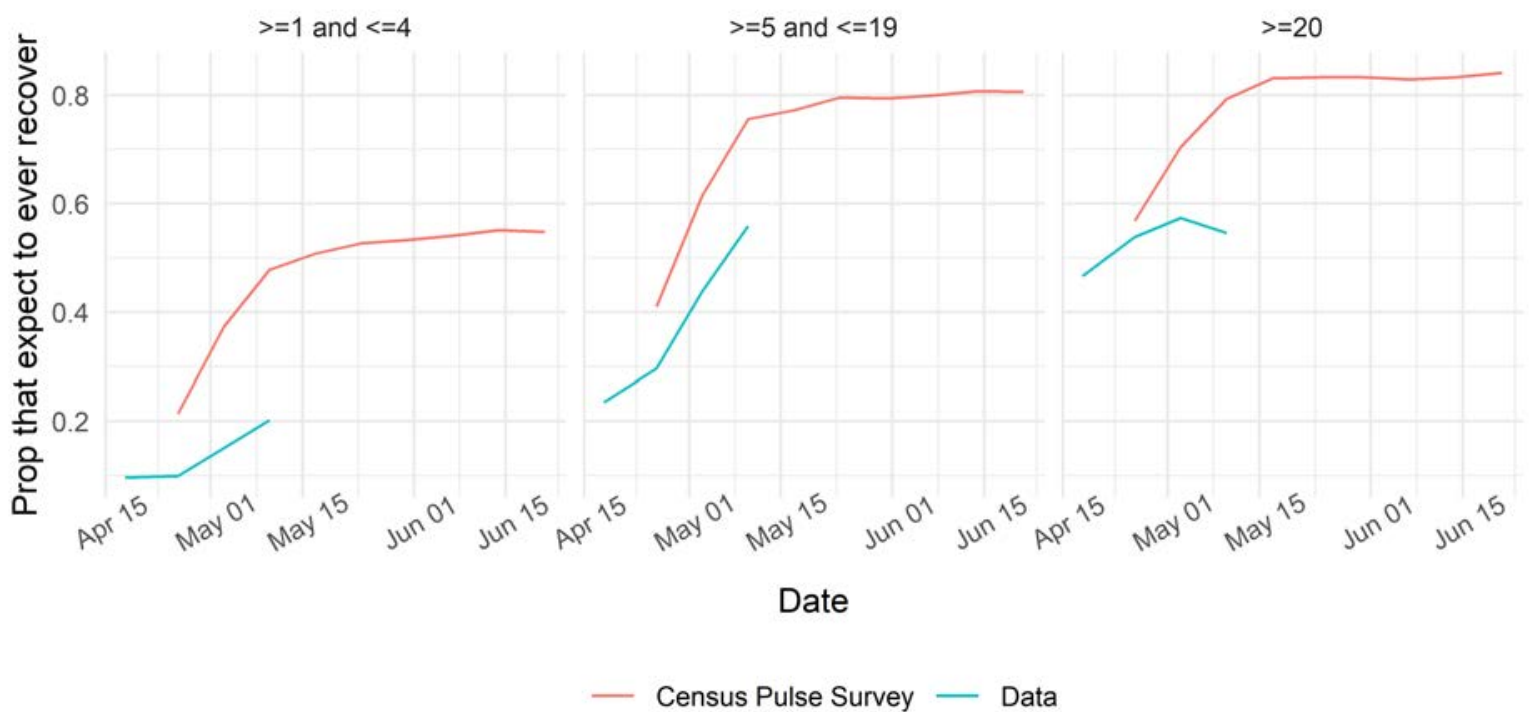

Note: Figure shows the weekly proportion of respondents from the survey who expected to ever recover (blue line) compared to weekly statistics from the Census Small Business Pulse Survey (red line). The three bins represent firm-size bins based on number of employees. The target population for the Census Pulse Survey was all nonfarm, single-location employer businesses 499 or less employees and receipts of $\$ 1,000$ or more in the 50 states, District of Columbia, and Puerto Rico and were drawn from the Business Register.

Figure 8: Comparing proportion that expect to ever recover (data vs. Census Pulse Survey)

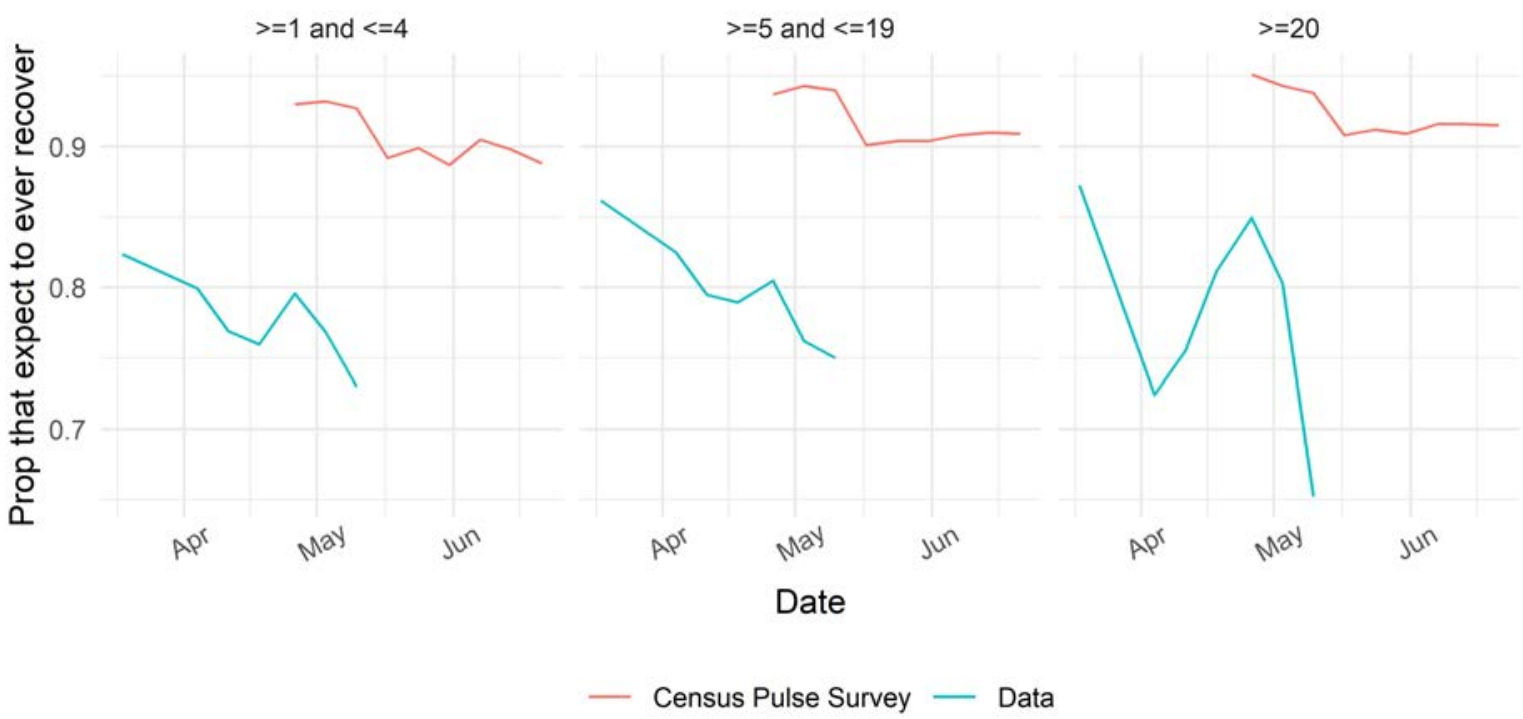

Note: Figure shows the weekly proportion of respondents from the survey who received a PPP loan (blue line) compared to weekly statistics from the Census Small Business Pulse Survey (red line). The three bins represent firm-size bins based on number of employees. The question used from the Census Pulse Survey was either "I do not believe this business will return to its usual level of operations." or "I do not believe this business will return to its normal level of operations relative to one year ago", then subtracted from one to align with the question in our surveys. The target population for the Census Pulse Survey was all nonfarm, single-location employer businesses 499 or less employees and receipts of $\$ 1,000$ or more in the 50 states, District of Columbia, and Puerto Rico and were drawn from the Business Register. 


\section{Appendix: Robustness of trends over time}

This section provides additional results to show that the trends shown in Figure 1 in the main paper are robust to potential changes in the composition of the sample over time. Table 5 provides regressions on days since 2020-03-27, or regressions with weekly dummy variables plus controls for the number of part-time and full-time employees in January, the day of the week the survey was taken, and state dummies. The top panel shows these regressions for if the firm expects to recover in the next two years. The first column regresses the outcome on days since 2020-03-27 while the second column uses week dummies. The third through fifth column repeats the second column, but conditions on the three firm-size bins used in the paper.

Table 6 uses respondents from the initial baseline survey who also completed the follow-up survey to study within-firm changes. Each panel shows the results of a regression of the withinfirm change in one of the outcomes on the days elapsed between the follow-up and baseline survey. The first column shows results for all firms, while columns 2 through 4 show results by firm size bins. All regressions control for cubic polynomials for full-time employment and part-time employment in January, the day of the week the baseline was take, state dummies, years of education, sex, age group dummies, firm type, firm sector, and dummies for the week the baseline survey was taken.

Figure 9 shows the size distribution of sample respondents by day. The top panel shows the proportion of respondents in each of the three size bins used in the paper. The bottom panel shows the average within those bins over time. 
Table 5: Trends in outcomes and expectations over time

\begin{tabular}{|c|c|c|c|c|c|}
\hline \multirow[b]{3}{*}{ Days since $2020-03-27$} & \multicolumn{5}{|c|}{ Recover in next 2 years } \\
\hline & \multicolumn{2}{|c|}{ All } & \multirow[t]{2}{*}{ 0-4.5 FTE } & \multirow[t]{2}{*}{ 5-9.5 FTE } & \multirow[t]{2}{*}{ 10-50 FTE } \\
\hline & $\begin{array}{c}-0.003^{* * *} \\
(0.0004)\end{array}$ & & & & \\
\hline Week of 2020-04-01 & & $\begin{array}{c}-0.049^{* *} \\
(0.023)\end{array}$ & $\begin{array}{c}-0.045^{*} \\
(0.027)\end{array}$ & $\begin{array}{l}-0.078 \\
(0.057)\end{array}$ & $\begin{array}{l}-0.047 \\
(0.073)\end{array}$ \\
\hline Week of 2020-04-08 & & $\begin{array}{c}-0.099^{* * *} \\
(0.024)\end{array}$ & $\begin{array}{c}-0.084^{* * *} \\
(0.028)\end{array}$ & $\begin{array}{c}-0.189^{* * *} \\
(0.058)\end{array}$ & $\begin{array}{l}-0.090 \\
(0.075)\end{array}$ \\
\hline Week of 2020-04-15 & & $\begin{array}{c}-0.146^{* * *} \\
(0.023)\end{array}$ & $\begin{array}{c}-0.130^{* * *} \\
(0.027)\end{array}$ & $\begin{array}{c}-0.234^{* * *} \\
(0.057)\end{array}$ & $\begin{array}{c}-0.141^{*} \\
(0.073)\end{array}$ \\
\hline Week of 2020-04-22 & & $\begin{array}{c}-0.136^{* * *} \\
(0.025)\end{array}$ & $\begin{array}{c}-0.122^{* * *} \\
(0.029)\end{array}$ & $\begin{array}{c}-0.226^{* * *} \\
(0.061)\end{array}$ & $\begin{array}{l}-0.111 \\
(0.077)\end{array}$ \\
\hline Week of 2020-04-29 & & $\begin{array}{c}-0.112^{* * *} \\
(0.025)\end{array}$ & $\begin{array}{c}-0.110^{* * *} \\
(0.029)\end{array}$ & $\begin{array}{c}-0.181^{* * *} \\
(0.060)\end{array}$ & $\begin{array}{l}-0.067 \\
(0.076)\end{array}$ \\
\hline Week of 2020-05-06 & & $\begin{array}{c}-0.155^{* * *} \\
(0.028)\end{array}$ & $\begin{array}{c}-0.140^{* * *} \\
(0.033)\end{array}$ & $\begin{array}{c}-0.238^{* * *} \\
(0.071)\end{array}$ & $\begin{array}{c}-0.168^{* *} \\
(0.085)\end{array}$ \\
\hline Week of 2020-05-13 & & $\begin{array}{c}-0.223^{* * *} \\
(0.038)\end{array}$ & $\begin{array}{c}-0.180^{* * *} \\
(0.046)\end{array}$ & $\begin{array}{c}-0.383^{* * *} \\
(0.086)\end{array}$ & $\begin{array}{c}-0.230^{* *} \\
(0.109)\end{array}$ \\
\hline \multirow[t]{3}{*}{$N$} & 13,741 & 13,741 & 9,486 & 2,507 & 1,748 \\
\hline & \multicolumn{5}{|c|}{ Ever Recover } \\
\hline & \multicolumn{2}{|c|}{ All } & $0-4.5 \mathrm{FTE}$ & 5-9.5 FTE & 10-50 FTE \\
\hline Days since $2020-03-27$ & $\begin{array}{c}-0.002^{* * *} \\
(0.0003)\end{array}$ & & & & \\
\hline Week of 2020-04-01 & & $\begin{array}{c}-0.050^{* * *} \\
(0.017)\end{array}$ & $\begin{array}{c}-0.040^{*} \\
(0.021)\end{array}$ & $\begin{array}{c}-0.079^{* *} \\
(0.038)\end{array}$ & $\begin{array}{l}-0.081 \\
(0.050)\end{array}$ \\
\hline Week of 2020-04-08 & & $\begin{array}{c}-0.075^{* * *} \\
(0.018)\end{array}$ & $\begin{array}{c}-0.070^{* * *} \\
(0.022)\end{array}$ & $\begin{array}{c}-0.116^{* * *} \\
(0.040)\end{array}$ & $\begin{array}{l}-0.071 \\
(0.051)\end{array}$ \\
\hline Week of $2020-04-15$ & & $\begin{array}{c}-0.099^{* * *} \\
(0.018)\end{array}$ & $\begin{array}{c}-0.087^{* * *} \\
(0.022)\end{array}$ & $\begin{array}{c}-0.155^{* * *} \\
(0.039)\end{array}$ & $\begin{array}{c}-0.118^{* *} \\
(0.050)\end{array}$ \\
\hline Week of 2020-04-22 & & $\begin{array}{c}-0.081^{* * *} \\
(0.019)\end{array}$ & $\begin{array}{c}-0.079^{* * *} \\
(0.023)\end{array}$ & $\begin{array}{c}-0.109^{* * *} \\
(0.042)\end{array}$ & $\begin{array}{l}-0.078 \\
(0.053)\end{array}$ \\
\hline Week of 2020-04-29 & & $\begin{array}{c}-0.079^{* * *} \\
(0.019)\end{array}$ & $\begin{array}{c}-0.071^{* * *} \\
(0.023)\end{array}$ & $\begin{array}{c}-0.145^{* * *} \\
(0.042)\end{array}$ & $\begin{array}{l}-0.057 \\
(0.053)\end{array}$ \\
\hline Week of 2020-05-06 & & $\begin{array}{c}-0.118^{* * *} \\
(0.023)\end{array}$ & $\begin{array}{c}-0.103^{* * *} \\
(0.027)\end{array}$ & $\begin{array}{c}-0.140^{* * *} \\
(0.052)\end{array}$ & $\begin{array}{c}-0.186^{* * *} \\
(0.066)\end{array}$ \\
\hline Week of 2020-05-13 & & $\begin{array}{c}-0.133^{* * *} \\
(0.032)\end{array}$ & $\begin{array}{c}-0.129^{* * *} \\
(0.040)\end{array}$ & $\begin{array}{c}-0.163^{* *} \\
(0.067)\end{array}$ & $\begin{array}{l}-0.142 \\
(0.090)\end{array}$ \\
\hline \multirow[t]{3}{*}{$N$} & 13,673 & 13,673 & 9,436 & 2,495 & 1,742 \\
\hline & \multicolumn{5}{|c|}{ Any layoffs } \\
\hline & \multicolumn{2}{|c|}{ All } & $0-4.5 \mathrm{FTE}$ & 5-9.5 FTE & 10-50 FTE \\
\hline Days since $2020-03-27$ & $\begin{array}{c}-0.0004 \\
(0.0003)\end{array}$ & & & & \\
\hline Week of 2020-04-01 & & $\begin{array}{c}0.076^{* * *} \\
(0.022)\end{array}$ & $\begin{array}{c}0.081^{* * *} \\
(0.026)\end{array}$ & $\begin{array}{c}0.084 \\
(0.053)\end{array}$ & $\begin{array}{c}0.127^{* *} \\
(0.062)\end{array}$ \\
\hline Week of 2020-04-08 & & $\begin{array}{c}0.099^{* * *} \\
(0.023)\end{array}$ & $\begin{array}{c}0.108^{* * *} \\
(0.026)\end{array}$ & $\begin{array}{c}0.085 \\
(0.053)\end{array}$ & $\begin{array}{c}0.144^{* *} \\
(0.064)\end{array}$ \\
\hline Week of 2020-04-15 & & $\begin{array}{c}0.092^{* * * *} \\
(0.022)\end{array}$ & $\begin{array}{c}0.098^{* * *} \\
(0.026)\end{array}$ & $\begin{array}{l}0.093^{*} \\
(0.052)\end{array}$ & $\begin{array}{c}0.111^{*} \\
(0.063)\end{array}$ \\
\hline Week of 2020-04-22 & & $\begin{array}{c}0.061^{* * * *} \\
(0.024)\end{array}$ & $\begin{array}{c}0.058^{* *} \\
(0.028)\end{array}$ & $\begin{array}{c}0.053 \\
(0.055)\end{array}$ & $\begin{array}{c}0.131^{* *} \\
(0.065)\end{array}$ \\
\hline Week of 2020-04-29 & & $\begin{array}{l}0.046^{*} \\
(0.024)\end{array}$ & $\begin{array}{c}0.053^{*} \\
(0.028)\end{array}$ & $\begin{array}{c}0.051 \\
(0.055)\end{array}$ & $\begin{array}{c}0.089 \\
(0.066)\end{array}$ \\
\hline Week of 2020-05-06 & & $\begin{array}{c}0.076^{* * *} \\
(0.027)\end{array}$ & $\begin{array}{c}0.087^{* * *} \\
(0.031)\end{array}$ & $\begin{array}{c}0.063 \\
(0.063)\end{array}$ & $\begin{array}{c}0.081 \\
(0.072)\end{array}$ \\
\hline Week of 2020-05-13 & & $\begin{array}{c}0.037 \\
(0.035)\end{array}$ & $\begin{array}{l}-0.004 \\
(0.043)\end{array}$ & $\begin{array}{c}0.096 \\
(0.075)\end{array}$ & $\begin{array}{c}0.181^{* *} \\
(0.079)\end{array}$ \\
\hline$N$ & 14,103 & 14,103 & 9,743 & 2,574 & 1,786 \\
\hline
\end{tabular}

Note: ${ }^{* * *}$ Significant at the 1 percent level, ${ }^{* *}$ significant at the 5 percent level, and ${ }^{*}$ significant at the 10 percent level. Column one shows the outcome regressed on days since 2020-03-28 while column two shows the outcome regressed on week dummies. The third and fourth columns repeat these results, but additionally control for number of part-time employees in January, number of full-time employees in January, the day of the week the survey was taken, and the state indicators. 
Table 6: Within-firm changes

\begin{tabular}{|c|c|c|c|c|}
\hline \multirow[b]{3}{*}{ Elapsed days } & \multicolumn{4}{|c|}{ Change in recover in next two years: } \\
\hline & All & $0-4.5$ & $5-9.5$ & $10-50$ \\
\hline & $\begin{array}{c}-0.004^{* *} \\
(0.002)\end{array}$ & $\begin{array}{c}-0.004^{* *} \\
(0.002)\end{array}$ & $\begin{array}{l}-0.002 \\
(0.004)\end{array}$ & $\begin{array}{l}-0.006 \\
(0.006)\end{array}$ \\
\hline \multirow[t]{3}{*}{$N$} & 2,605 & 1,804 & 478 & 323 \\
\hline & \multicolumn{4}{|c|}{ Change in ever recover: } \\
\hline & All & $0-4.5$ & $5-9.5$ & $10-50$ \\
\hline Elapsed days & $\begin{array}{c}-0.003^{* *} \\
(0.001)\end{array}$ & $\begin{array}{c}-0.003^{*} \\
(0.002)\end{array}$ & $\begin{array}{c}-0.003 \\
(0.003)\end{array}$ & $\begin{array}{l}-0.005 \\
(0.005)\end{array}$ \\
\hline \multirow[t]{3}{*}{$N$} & 2,594 & 1,795 & 476 & 323 \\
\hline & \multicolumn{4}{|c|}{ Change in past layoffs } \\
\hline & All & $0-4.5$ & $5-9.5$ & $10-50$ \\
\hline Elapsed days & $\begin{array}{c}0.006^{* * *} \\
(0.002)\end{array}$ & $\begin{array}{l}0.005^{* *} \\
(0.002)\end{array}$ & $\begin{array}{c}0.018^{* * *} \\
(0.006)\end{array}$ & $\begin{array}{c}0.005 \\
(0.007)\end{array}$ \\
\hline \multirow[t]{3}{*}{$N$} & 2,672 & 1,847 & 491 & 334 \\
\hline & \multicolumn{4}{|c|}{ Change in awareness of programs } \\
\hline & All & $0-4.5$ & $5-9.5$ & $10-50$ \\
\hline Elapsed days & $\begin{array}{c}-0.002 \\
(0.001)\end{array}$ & $\begin{array}{l}-0.002 \\
(0.002)\end{array}$ & $\begin{array}{l}-0.001 \\
(0.003)\end{array}$ & $\begin{array}{l}-0.003 \\
(0.004)\end{array}$ \\
\hline$N$ & 2,620 & 1,815 & 480 & 325 \\
\hline
\end{tabular}

Note: ${ }^{* * *}$ Significant at the 1 percent level, ${ }^{* *}$ significant at the 5 percent level, and ${ }^{*}$ significant at the 10 percent level. Table shows the change in outcomes for firms who completed follow-up surveys. The first four columns show results for those who completed their follow-up before 2020-04-27, while the second four columns show results for all follow-ups. For each set of four columns, the table shows results for all firms, and then by firm size bin. All regressions control for cubic polynomials for full-time employment and part-time employment in January, the day of the week the baseline was take, state dummies, years of education, sex, age group dummies, firm type, firm sector, and dummies for the week the baseline survey was taken. 
Figure 9: Firm size across days of the survey
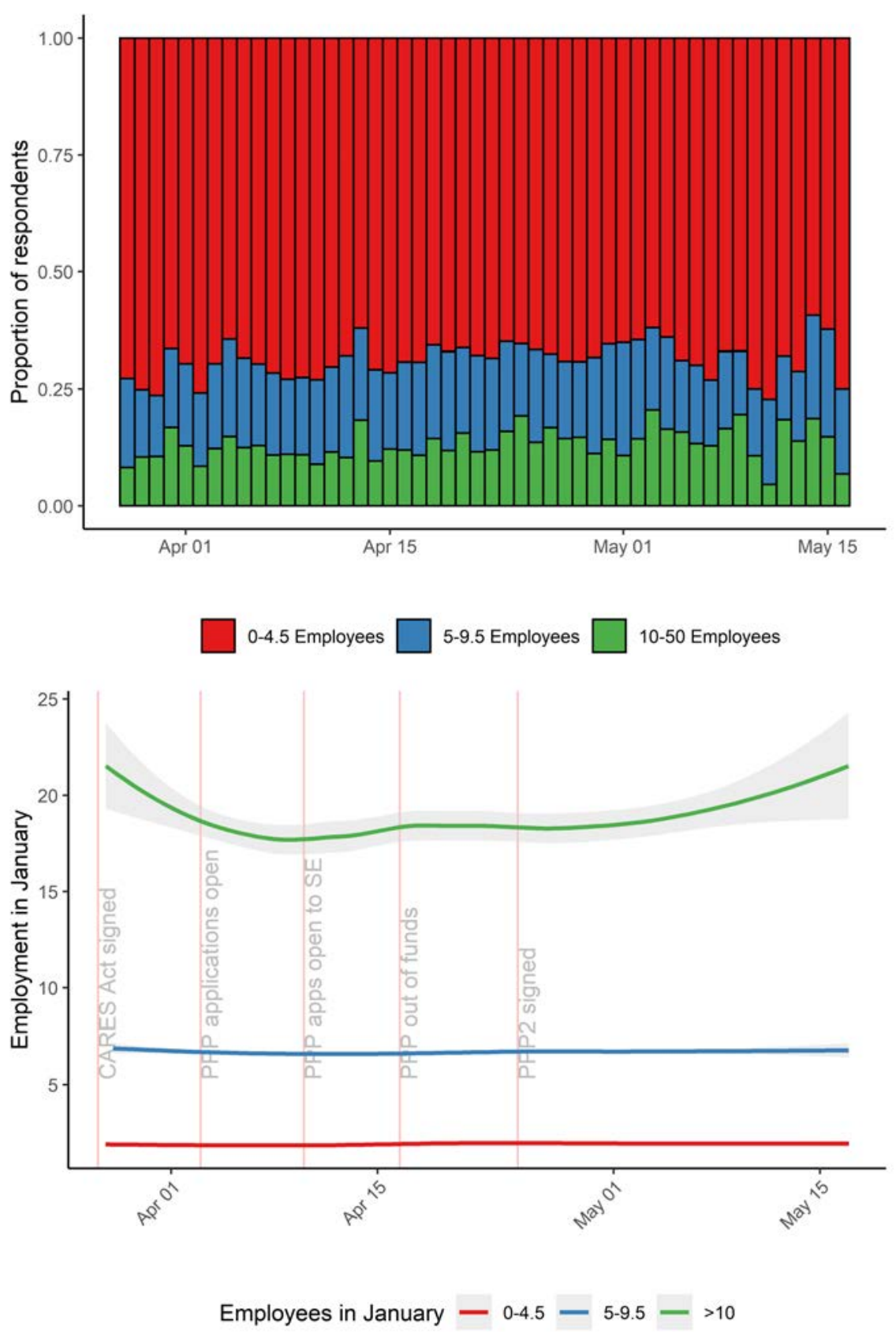

Note: The top panel shows the proportion of daily respondents in three size bins based on their FTE employment in January (0-4.5 employees, 5-9.5 employees, 10-50 employees). The bottom panel shows a loess regression by size bin size with $95 \%$ confidence intervals shown in grey. 


\section{D.1 Trends in awareness of programs over time}

Figure 10: Awareness of government programs over time (programs that help cover payroll)
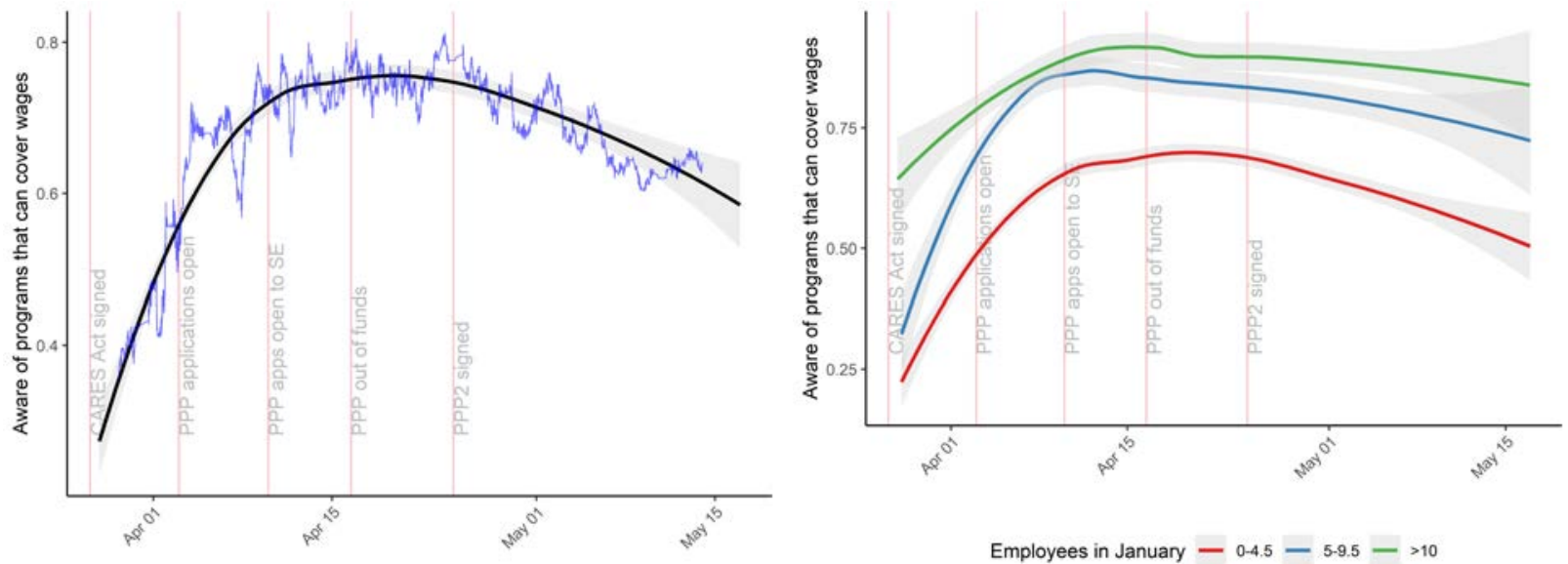

Note: In the left panel, the black line is fit using locally weighted smoothing regression, with the grey region showing the $95 \%$ confidence interval. The blue line shows a centered moving average over 250 responses. The right panel shows loess regression lines over time by business size bin.

Figure 11: Awareness of government programs over time (subsidized loans)
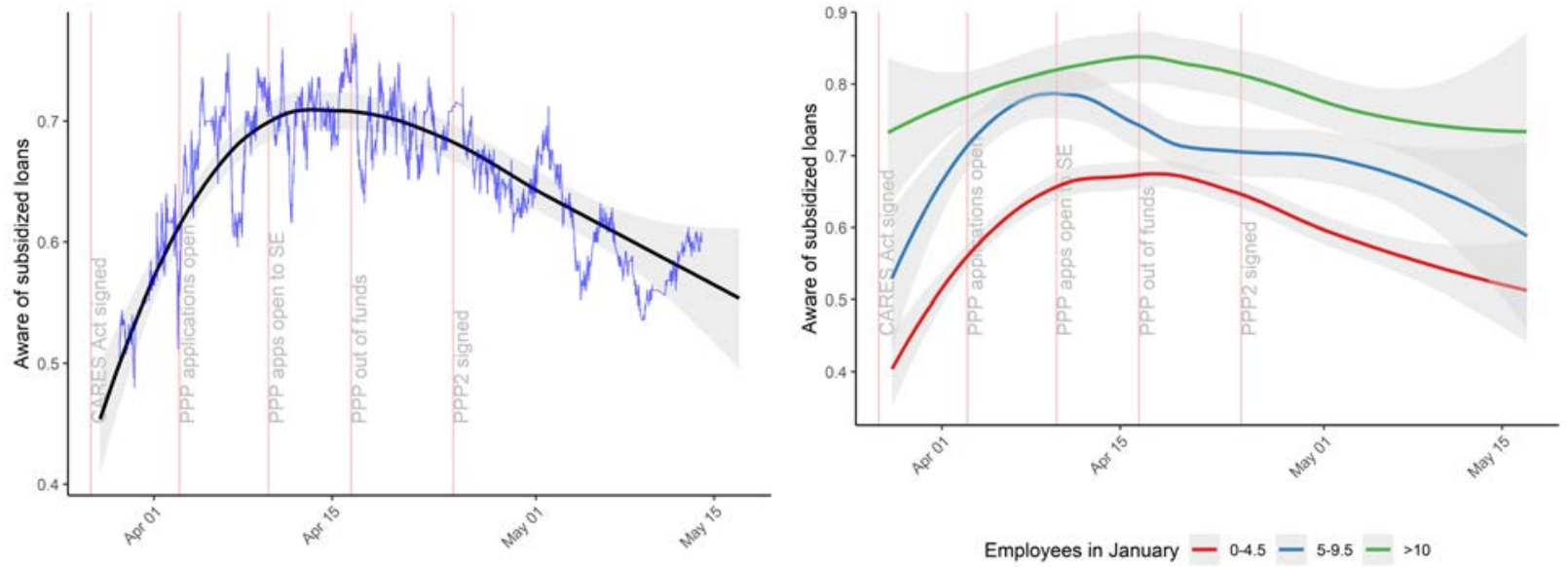

Note: In the left panel, the black line is fit using locally weighted smoothing regression, with the grey region showing the $95 \%$ confidence interval. The blue line shows a centered moving average over 250 responses. The right panel shows loess regression lines over time by business size bin. 


\section{E Appendix: Additional results related to the Paycheck Protection Program}

This section provides additional results to supplement the analysis of who applies for a PPP loan and the benefits associated with getting a loan from the main paper. Tables 7, 8 and 9 supplement Table 1 from the paper. The first repeats the analysis in the main paper with additional controls for the number of cases and deaths in the state at the time of the study, as well as zip-code level demographic characteristics, and measures of distance to SBA approved

lenders. The second restricts the sample to those who completed the baseline and follow-up survey and controls for baseline beliefs. The fourth repeats the analysis, but with four size-bins for firms, separating firms with no employees in January from the 0 to 4.5 group.

Tables 10 and 11 provides robustness for Table 2 from the paper. Table 10 extends Table 2 by adding a number of location-based controls, including the number of cases and deaths in the state at the time of the study, as well as zip-code level demographic characteristics, and measures of distance to SBA approved lenders. Table 11 restricts the analysis to the sub-sample who completed the original baseline survey and then completed the follow-up survey and adds additional controls for the baseline responses for the probability of bankruptcy or closure in the next six months, if they expected to recover in the next two years, and if they ever expected to recover. 
Table 7: PPP timing by firm characteristics (additional controls)

Jan. FTE Emp 0-4.5

Jan. FTE Emp 5-9.5

Years of schooling

Type: LLC

Type: Other

Type: Self-employed

Type: Sole prop or part

Cases per capita

Deaths per capita

Median HH income

Suburban

Urban

Min distance to SBA lender

Num of approved lenders within $10 \mathrm{~km}$

Prop. Black

Prop. Asian

Prop. Hispanic

Prop. HS graduates

Prop. 4-year coll grads

Prop. Unemployed
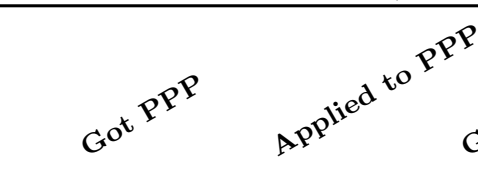

$-0.264^{* * *}-$

(0.020)

$-0.112^{* * *}$

(0.024)

$0.008^{* * *}$

(0.003)

$-0.080^{* * *}$

(0.018)

$-0.012$

(0.055)

$-0.187^{* * *}$

(0.022)

$-0.156^{* * *}$

(0.016)

$-0.0002$

$(0.0002)$

0.003

(0.002)

$-0.0002$

(0.0004)

$-0.020$

$(0.016)$

$-0.007$

$(0.020)$

0.00002

(0.001)

$-0.0001$

(0.0001)

$0.107^{*}$

(0.062)

0.115

(0.112)

$-0.081$

(0.051)

$-0.232$

(0.177)

$0.177^{* *}$

(0.078)

$-0.489^{*}$

(0.252)

4,927

$N$
$\mathrm{R}^{2}$

0.169
$-0.220^{* *}$

(0.020)

$-0.005$

(0.022)

$0.014^{* * *}$

(0.003)

$-0.081^{* * *}$

(0.020)

$-0.138^{* *}$

(0.059)

$-0.268^{* * *}$

(0.038)

$-0.218^{* * *}$

(0.020)

0.0001

(0.0003)

$-0.002$

(0.003)

0.001

(0.0004)

0.019

(0.020)

$0.065^{* * *}$

(0.025)

$-0.002$

(0.001)

0.0001

(0.0001)

$-0.001$

(0.079)

0.154

(0.145)

$-0.128^{*}$

(0.067)

$-0.303$

$(0.235)$

$0.184^{*}$

(0.100)

$-0.352$

(0.341)

(0.341)

4,927

0.144
$-0.270^{* * *} \quad 1.623^{* * *}$

(0.025)

$-0.143^{* * *}$

(0.027)

$0.009^{* *}$

(0.004)

$-0.066^{* * *}$

(0.024)

0.077

(0.077)

$-0.224^{* * *}$

(0.049)

$-0.174^{* * *}$

(0.025)

$-0.0005$

(0.0004)

$0.008^{* *}$

(0.004)

$-0.001$

(0.001)

$-0.051^{* *}$

(0.025)

$-0.077^{* *}$

(0.032)

$-0.0003$

(0.003)

$-0.0001$

(0.0001)

$0.239^{* *}$

(0.100)

0.176

$(0.165)$

$-0.096$

$(0.090)$

$-0.135$

(0.306)

0.132

(0.135)

$-0.938^{*}$

(0.492)

2,619

2,619
0.221
$(0.563)$

$\begin{array}{ll}-0.038 & 0.721\end{array}$

(0.589) (1.085)

$\begin{array}{ll}-0.014 & 0.239\end{array}$

(0.112) (0.207)

$0.917 \quad 2.724^{* *}$

(0.604) (1.143)

$3.445^{*} \quad-3.782$

(1.943) (2.883)

$1.7215 .224^{*}$

(1.608) (2.860)

$0.954 \quad 2.494^{*}$

(0.661) (1.281)

$0.001 \quad 0.039^{*}$

$(0.014) \quad(0.022)$
0.088

$0.088 \quad-0.194$

$(0.133) \quad(0.216)$

$-0.017 \quad-0.001$

$(0.015) \quad(0.025)$

$-0.543 \quad 1.312$

(0.623) (1.189)

$0.092 \quad-0.295$

(0.851) (1.553)

$0.033 \quad-0.151$

$(0.062) \quad(0.141)$

$0.001 \quad 0.003$

(0.002) (0.004)

$-1.054 \quad 1.970$

(2.611) (4.615)

$-0.714 \quad 10.437$

(4.724) (7.188)

$0.433 \quad 0.549$

(2.316) (3.742)

$6.057-28.126^{*}$

(8.686) (15.356)

$\begin{array}{ll}-3.776 & 9.353\end{array}$

(3.620) (6.260)

$\begin{array}{ll}-11.122 & -16.868\end{array}$

(13.138) (24.381)

$1,321 \quad 517$

$\begin{array}{ll}1,321 & 517 \\ 0.112 & 0.442\end{array}$

Note: ${ }^{* * *}$ Significant at the 1 percent level, ${ }^{* *}$ significant at the 5 percent level, and ${ }^{*}$ significant at the 10 percent level. The first four specifications control for the date the survey was taken. The final regression controls for the day the first PPP loan application was submitted and the week the survey was taken. All regressions also include controls for industry, age groups, and gender, but coefficients were largely not statistically significant nor large and are not displayed as they largely did not predict the outcomes. All regressions additionally control for state of residence. The omitted category for firm type is C-Corps and S-Corps. The omitted category for firm-size bins is firms with 10 to 50 FTE employees. Columns 4 and 5 have fewer observations as many respondents did not provide the dates of their application and approval. Cases and deaths are per 100 thousand in the state by the day of the survey. "Min dist to SBA lender" is the minimum distance from the ZIP code centroid to the closest SBA lender listed on sba.gov in kilometers. Similarly, "Num of approved lenders within 10km" is the number of approved SBA lenders listed on sba.gov within 10 kilometers of the zip code centroid. All other new outcomes are constructed from the 5-year 2018 ACS and are ZIP code level (ZCTA) outcomes. Median household income is in tens of thousands of dollars. 
Table 8: PPP timing by firm characteristics (controlling for baseline expectations)

Jan. FTE Emp 0-4.5

Jan. FTE Emp 5-9.5

Years of schooling

Type: LLC

Type: Other

Type: Self-employed

Type: Sole prop or part

Baseline prob. of bankruptcy or closure

Baseline recover next two years

Baseline ever recover

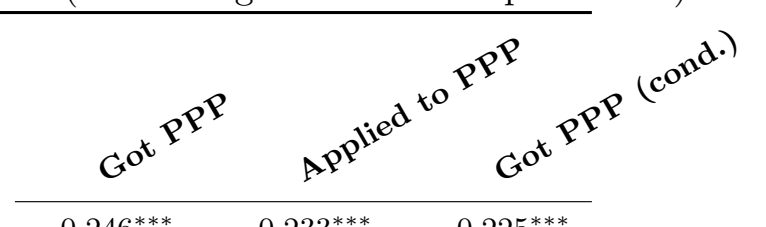$$
(0.028)
$$

$-0.165^{* * *}$

(0.032)

$0.009^{* * *}$

(0.003)

$-0.069^{* * *}$

(0.023)

0.051

(0.085)

$-0.192^{* * *}$

(0.029)

$-0.170^{* * *}$

(0.021)

$-0.055^{*}$

(0.030)

$0.032^{*}$

(0.017)

$-0.001$

(0.022)

2,593

2,593

0.194
$-0.233^{* * *}$

(0.028)

$-0.041$

(0.031)

$0.016^{* * *}$

(0.004)

$-0.062^{* *}$

(0.025)

$-0.163^{*}$

(0.086)

$-0.313^{* * *}$

(0.056)

$-0.227^{* * *}$

(0.027)

0.032

(0.041)

$-0.032$

(0.024)

$0.068^{* *}$

(0.031)

2.593

2,593

0.176
$-0.225^{* * *}$

(0.035)

$-0.180^{* * *}$

(0.039)

$0.011^{* *}$

(0.005)

$-0.064^{* *}$

(0.031)

$0.246^{* *}$

(0.114)

$-0.215^{* * *}$

(0.075)

$-0.194^{* * *}$

(0.031)

$-0.145^{* * *}$

(0.053)

$0.056^{* *}$

(0.028)

$-0.036$

(0.038)

(0.038)

1,374

0.263

$N$
$\mathrm{R}^{2}$

Note: ${ }^{* * *}$ Significant at the 1 percent level, ${ }^{* *}$ significant at the 5 percent level, and ${ }^{*}$ significant at the 10 percent level. Sample is restricted to those taking both the baseline and follow-up surveys. All specifications control for the date the survey was taken, firm industry, age groups, gender, and state of residence. The omitted category for firm type is C-Corps and S-Corps. The omitted category for firm-size bins is firms with 10 to 50 FTE employees. Columns 4 and 5 have fewer observations as many respondents did not provide the dates of their application and approval. Alternative specifications of these results are included in Appendix E. These include a table replicating these results controlling for additional state and ZIP code level characteristics, results controlling for baseline beliefs of the firms, and results separating firms with zero employees into their own group. 
Table 9: PPP outcomes by firm characteristics (4 firm size bins)

Jan. FTE Emp 0

Jan. FTE Emp 0.5-4.5

Jan. FTE Emp 5-9.5

Years of schooling

Type: LLC

Type: Other

Type: Self-employed

Type: Sole prop or part

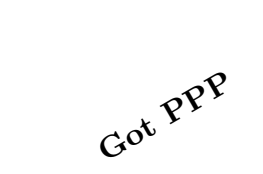

$-0.320^{* * *}$

$(0.024)$

$-0.263^{* * *}$

(0.020)

$-0.117^{* * *}$

(0.024)

$0.009^{* * *}$

(0.003)

$-0.078^{* * *}$

(0.018)

$-0.009$

(0.055)

$-0.190^{* * *}$

(0.022)

$-0.157^{* * *}$

(0.016)

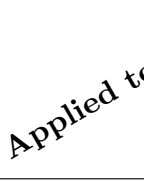

$-0.387^{* * *}$

(0.035)

$-0.220^{* * *}$

(0.020)

$-0.012$

(0.022)

$0.017^{* * *}$

(0.003)

$-0.079^{* * *}$

(0.020)

$-0.138^{* *}$

(0.058)

$-0.280^{* * *}$

(0.038)

$-0.221^{* * *}$

(0.020)

4,996

4,996

0.135

0.166

0.135

Note: ${ }^{* * *}$ Significant at the 1 percent level, ${ }^{* *}$ significant at the 5 percent level, and ${ }^{*}$ significant at the 10 percent level. The first four specifications control for the date the survey was taken. The final regression controls for the day the first PPP loan application was submitted and the week the survey was taken. All regressions also include controls for industry, age groups, and gender, but coefficients were largely not statistically significant nor large and are not displayed as they largely did not predict the outcomes. All regressions additionally control for state of residence. The omitted category for firm type is C-Corps and S-Corps. The omitted category for firm-size bins is firms with 10 to 50 FTE employees.Columns 4 and 5 have fewer observations as many respondents did not provide the dates of their application and approval. 
Table 10: PPP loans and business outcomes (additional controls)

\begin{tabular}{|c|c|c|c|c|c|c|c|c|}
\hline \multirow[b]{3}{*}{ PPP } & \multicolumn{8}{|c|}{ Recover in next 2 years } \\
\hline & \multicolumn{2}{|c|}{ All } & \multicolumn{2}{|c|}{ 0-4.5 FTE } & \multicolumn{2}{|c|}{ 5-9.5 FTE } & \multicolumn{2}{|c|}{ 10-50 FTE } \\
\hline & $\begin{array}{c}0.083^{* * *} \\
(0.019)\end{array}$ & & $\begin{array}{c}0.120^{* * *} \\
(0.027)\end{array}$ & & $\begin{array}{l}0.080^{* *} \\
(0.041)\end{array}$ & & $\begin{array}{l}-0.012 \\
(0.045)\end{array}$ & \\
\hline PPP (cond) & & $\begin{array}{c}0.122^{* * *} \\
(0.022)\end{array}$ & & $\begin{array}{c}0.143^{* * *} \\
(0.032)\end{array}$ & & $\begin{array}{c}0.156^{* * *} \\
(0.049)\end{array}$ & & $\begin{array}{l}-0.016 \\
(0.059)\end{array}$ \\
\hline \multirow[t]{3}{*}{$N$} & 4,883 & 2,619 & 3,308 & 1,463 & 904 & 652 & 671 & 504 \\
\hline & \multicolumn{8}{|c|}{ Prob of closure or bankruptcy } \\
\hline & \multicolumn{2}{|c|}{ All } & \multicolumn{2}{|c|}{ 0-4.5 FTE } & \multicolumn{2}{|c|}{ 5-9.5 FTE } & \multicolumn{2}{|c|}{ 10-50 FTE } \\
\hline PPP & $\begin{array}{c}-0.082^{* * *} \\
(0.009)\end{array}$ & & $\begin{array}{c}-0.083^{* * *} \\
(0.014)\end{array}$ & & $\begin{array}{c}-0.087^{* * *} \\
(0.020)\end{array}$ & & $\begin{array}{c}-0.079^{* * *} \\
(0.021)\end{array}$ & \\
\hline PPP (cond) & & $\begin{array}{c}-0.107^{* * *} \\
(0.011)\end{array}$ & & $\begin{array}{c}-0.103^{* * *} \\
(0.016)\end{array}$ & & $\begin{array}{c}-0.115^{* * *} \\
(0.024)\end{array}$ & & $\begin{array}{c}-0.103^{* * *} \\
(0.027)\end{array}$ \\
\hline \multirow[t]{3}{*}{$N$} & 4,883 & 2,619 & 3,308 & 1,463 & 904 & 652 & 671 & 504 \\
\hline & \multicolumn{8}{|c|}{ Current employment } \\
\hline & \multicolumn{2}{|c|}{ All } & \multicolumn{2}{|c|}{ 0-4.5 FTE } & \multicolumn{2}{|c|}{ 5-9.5 FTE } & \multicolumn{2}{|c|}{ 10-50 FTE } \\
\hline PPP & $\begin{array}{c}0.548^{* * *} \\
(0.170)\end{array}$ & & $\begin{array}{c}0.226^{* * *} \\
(0.070)\end{array}$ & & $\begin{array}{c}0.783^{* * *} \\
(0.224)\end{array}$ & & $\begin{array}{c}0.883 \\
(0.726)\end{array}$ & \\
\hline PPP (cond) & & $\begin{array}{c}0.528^{* * *} \\
(0.185)\end{array}$ & & $\begin{array}{c}0.244^{* * *} \\
(0.077)\end{array}$ & & $\begin{array}{c}0.877^{* * *} \\
(0.261)\end{array}$ & & $\begin{array}{c}0.884 \\
(0.904)\end{array}$ \\
\hline \multirow[t]{3}{*}{$N$} & 4,883 & 2,619 & 3,308 & 1,463 & 904 & 652 & 671 & 504 \\
\hline & \multicolumn{8}{|c|}{ Past layoffs } \\
\hline & & & $0-4$. & FTE & $5-9$ & FTE & $10-5$ & FTE \\
\hline PPP & $\begin{array}{c}-0.083^{* * *} \\
(0.018)\end{array}$ & & $\begin{array}{c}-0.113^{\text {*** }} \\
(0.027)\end{array}$ & & $\begin{array}{l}-0.053 \\
(0.039)\end{array}$ & & $\begin{array}{c}-0.073^{*} \\
(0.038)\end{array}$ & \\
\hline PPP (cond) & & $\begin{array}{c}-0.110^{* * *} \\
(0.021)\end{array}$ & & $\begin{array}{c}-0.132^{* * *} \\
(0.030)\end{array}$ & & $\begin{array}{c}-0.089^{* *} \\
(0.045)\end{array}$ & & $\begin{array}{l}-0.059 \\
(0.048)\end{array}$ \\
\hline$N$ & 4,883 & 2,619 & 3,308 & 1,463 & 904 & 652 & 671 & 504 \\
\hline
\end{tabular}

Note: ${ }^{* * *}$ Significant at the 1 percent level, ${ }^{* *}$ significant at the 5 percent level, and ${ }^{*}$ significant at the 10 percent level. "PPP" is an indicator for if the business received a PPP loan while "PPP (cond)" is the same regression, but restricted to those who applied to the PPP program. The first two columns show results for the full sample, while the remaining columns show results conditional on firm size bins. All regressions control for a third order polynomial in the number of full-time employees in January, a third order polynomial in the number of part-time employees in January, the day of the week the survey was completed, state dummies, years of education dummies, gender, age group dummies, firm type, firm sector, and the date the survey was completed. Compared to Table 2, this table additionally controls for total cases and deaths per capita in the state as of the day of the survey, median household income for the ZIP code, indicators for urban/rural/suburban for the ZIP code, minimum distance to SBA approved lender from ZIP centroid, number of SBA approved lenders within 10 kilometers of the ZIP centroid, proportions of the population in the zip code that is Hispanic, Asian, and Black; the proportion of residents with with a high school degree or more, the proportion of residents with a 4-year degree or more, and the unemployment rate in the zip code. 
Table 11: PPP loans and business outcomes (controlling for baseline expectations)

\begin{tabular}{|c|c|c|c|c|c|c|c|c|}
\hline \multirow[b]{3}{*}{ PPP } & \multicolumn{8}{|c|}{ Recover in next 2 years } \\
\hline & \multicolumn{2}{|c|}{ All } & \multicolumn{2}{|c|}{$0-4.5 \mathrm{FTE}$} & \multicolumn{2}{|c|}{ 5-9.5 FTE } & \multicolumn{2}{|c|}{ 10-50 FTE } \\
\hline & $\begin{array}{c}0.010 \\
(0.023)\end{array}$ & & $\begin{array}{c}0.054^{*} \\
(0.030)\end{array}$ & & $\begin{array}{l}-0.001 \\
(0.053)\end{array}$ & & $\begin{array}{l}-0.080 \\
(0.057)\end{array}$ & \\
\hline PPP (cond) & & $\begin{array}{c}0.031 \\
(0.026)\end{array}$ & & $\begin{array}{c}0.086^{* *} \\
(0.036)\end{array}$ & & $\begin{array}{c}0.076 \\
(0.064)\end{array}$ & & $\begin{array}{c}-0.167^{* *} \\
(0.072)\end{array}$ \\
\hline \multirow[t]{3}{*}{$N$} & 2,547 & 1,374 & 1,763 & 790 & 468 & 338 & 316 & 246 \\
\hline & \multicolumn{8}{|c|}{ Prob of closure or bankruptcy } \\
\hline & \multicolumn{2}{|c|}{ All } & \multicolumn{2}{|c|}{$0-4.5 \mathrm{FTE}$} & \multicolumn{2}{|c|}{ 5-9.5 FTE } & \multicolumn{2}{|c|}{ 10-50 FTE } \\
\hline PPP & $\begin{array}{c}-0.033^{* * *} \\
(0.010)\end{array}$ & & $\begin{array}{c}-0.034^{* * *} \\
(0.013)\end{array}$ & & $\begin{array}{c}-0.058^{* *} \\
(0.023)\end{array}$ & & $\begin{array}{l}-0.022 \\
(0.025)\end{array}$ & \\
\hline PPP (cond) & & $\begin{array}{c}-0.049^{* * *} \\
(0.011)\end{array}$ & & $\begin{array}{c}-0.045^{* * *} \\
(0.015)\end{array}$ & & $\begin{array}{c}-0.077^{* * *} \\
(0.029)\end{array}$ & & $\begin{array}{l}-0.016 \\
(0.032)\end{array}$ \\
\hline \multirow[t]{3}{*}{$N$} & 2,547 & 1,374 & 1,763 & 790 & 468 & 338 & 316 & 246 \\
\hline & \multicolumn{8}{|c|}{ Current employment } \\
\hline & \multicolumn{2}{|c|}{ All } & \multicolumn{2}{|c|}{$0-4.5 \mathrm{FTE}$} & \multicolumn{2}{|c|}{ 5-9.5 FTE } & \multicolumn{2}{|c|}{ 10-50 FTE } \\
\hline PPP & $\begin{array}{c}0.460^{* *} \\
(0.225)\end{array}$ & & $\begin{array}{c}0.082 \\
(0.085)\end{array}$ & & $\begin{array}{c}0.137 \\
(0.314)\end{array}$ & & $\begin{array}{c}1.434 \\
(1.172)\end{array}$ & \\
\hline PPP (cond) & & $\begin{array}{c}0.209 \\
(0.258)\end{array}$ & & $\begin{array}{l}-0.006 \\
(0.094)\end{array}$ & & $\begin{array}{c}0.034 \\
(0.385)\end{array}$ & & $\begin{array}{l}-0.234 \\
(1.526)\end{array}$ \\
\hline \multirow[t]{3}{*}{$N$} & 2,547 & 1,374 & 1,763 & 790 & 468 & 338 & 316 & 246 \\
\hline & \multicolumn{8}{|c|}{ Past layoffs } \\
\hline & & & $0-4$. & FTE & $5-9$. & FTE & $10-5$ & FTE \\
\hline PPP & $\begin{array}{c}-0.014 \\
(0.027)\end{array}$ & & $\begin{array}{l}-0.047 \\
(0.036)\end{array}$ & & $\begin{array}{c}0.062 \\
(0.065)\end{array}$ & & $\begin{array}{l}-0.012 \\
(0.069)\end{array}$ & \\
\hline PPP (cond) & & $\begin{array}{l}-0.025 \\
(0.031)\end{array}$ & & $\begin{array}{c}-0.034 \\
(0.041)\end{array}$ & & $\begin{array}{c}0.035 \\
(0.079)\end{array}$ & & $\begin{array}{l}-0.002 \\
(0.089)\end{array}$ \\
\hline$N$ & 2,547 & 1,374 & 1,763 & 790 & 468 & 338 & 316 & 246 \\
\hline
\end{tabular}

Note: ${ }^{* *}$ Significant at the 1 percent level, ${ }^{* *}$ significant at the 5 percent level, and ${ }^{*}$ significant at the 10 percent level. Sample is restricted to those who completed both the baseline and follow up survey. "PPP" is an indicator for if the business received a PPP loan while "PPP (cond)" is the same regression, but restricted to those who applied to the PPP program. Compared to Table 2, these results additionally control for the baseline probability of bankruptcy or closure, the baseline belief on if the firm would recover in the next two years, and the baseline belief on if the firm would ever recover. The first two columns show results for the full sample, while the remaining columns show results conditional on firm size bins. All regressions control for a third order polynomial in the number of full-time employees in January, a third order polynomial in the number of part-time employees in January, the day of the week the survey was completed, state dummies, years of education dummies, gender, age group dummies, firm type, firm sector, and the date the survey was completed. 